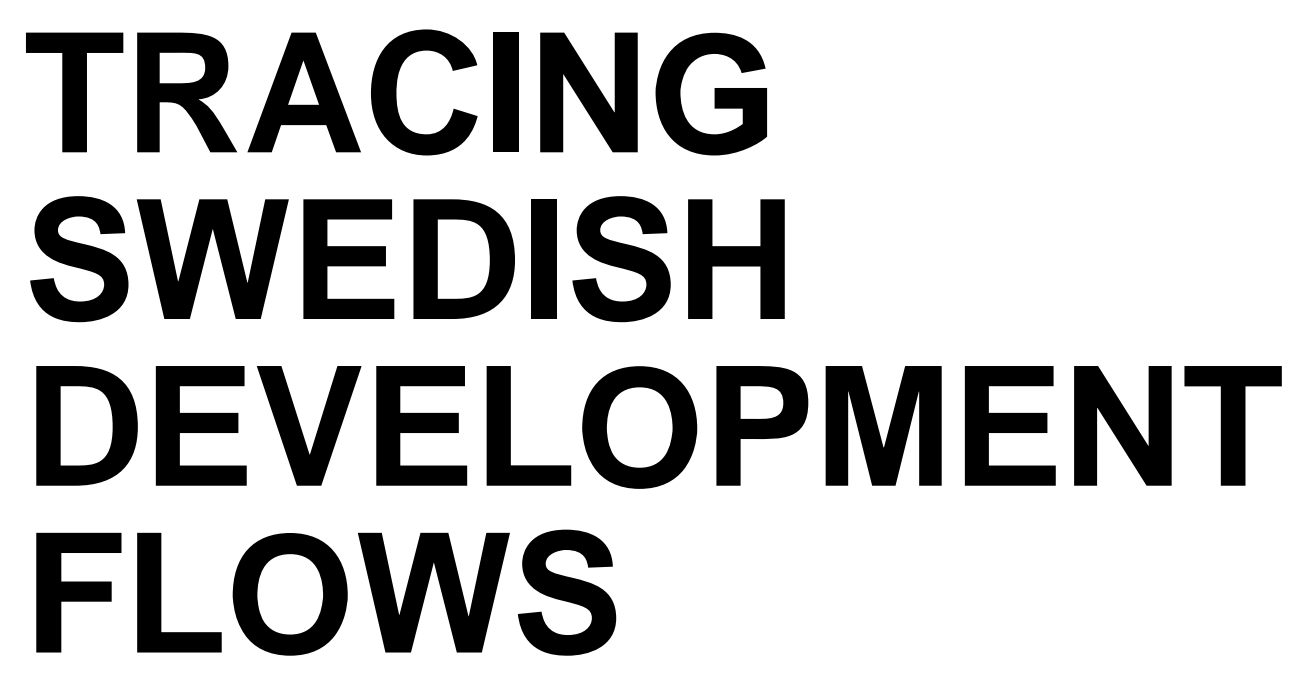

\title{
A study of the traceability of Swedish aid to Tanzania
}

\section{MARC J. COHEN AND TIGIST MEKURIA}

Oxfam

Using 2013-2015 International Aid Transparency Initiative (IATI) data, we trace Swedish aid to Tanzania to its end use. General budget support (GBS) accounted for much of Swedish aid in 2013 and 2015, but we cannot determine final expenditures using IATI data. In 2014, in the absence of GBS, we can only confirm that 28 percent of Swedish aid arrived in Tanzania, via the government and Tanzania-based organizations. A key constraint to traceability is that Sweden does not require aid implementers to report to IATI. We recommend that Sweden encourage such reporting.

This research report was written to share research results, to contribute to public debate and to invite feedback on development and humanitarian policy and practice. It does not necessarily reflect the policy positions of the organizations jointly publishing it. The views expressed are those of the author and not necessarily those of the individual organizations. 


\section{CONTENTS}

Executive summary …......................................................... 3

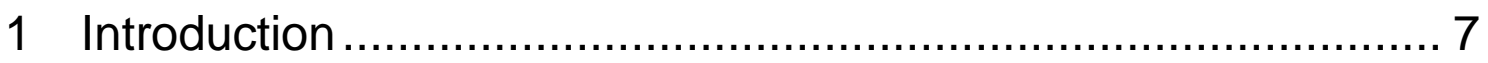

2 Tracing Swedish aid to Tanzania using IATI data ................... 12

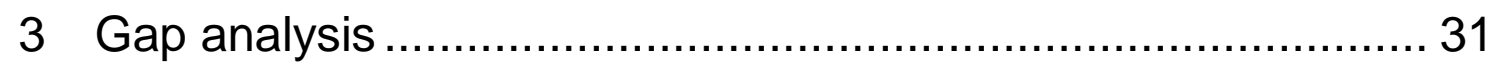

4 Alignment between Swedish AID and the Tanzanian budget ... 33

5 Conclusions and recommendations .................................... 34

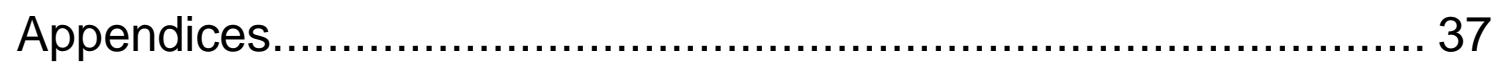

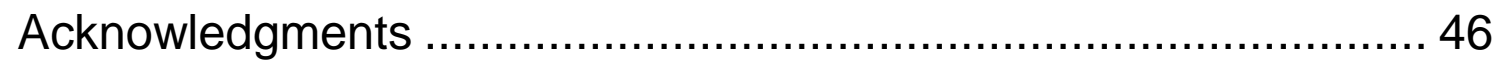

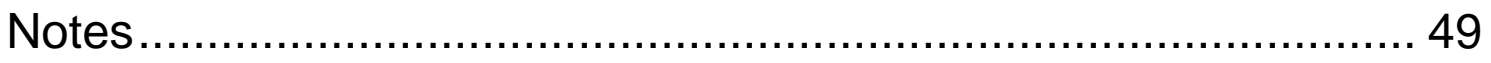




\section{EXECUTIVE SUMMARY}

Aid transparency helps advance sustainable development in four ways:

1. It provides government officials with better information to help them allocate resources.

2. It provides civil society actors with better information to help them hold government to account.

3. It helps the multiple actors and stakeholders involved in development coordinate their activities.

4. It helps people everywhere who care about development share and learn from their experiences.

The International Aid Transparency Initiative (IATI) was launched at the third High-Level Forum on Aid Effectiveness in Accra in 2008 to facilitate the efforts of aid donors and development organizations to act on their transparency commitments. In 2011, IATI's Steering Committee agreed to the IATI Standard, a list of information that development cooperation organizations should publish, along with technical instructions for representing that information as structured open data in machine-readable format. As of the end of April 2018, 700 development organizations published their data to IATI. ${ }^{1}$ Many new publishers came on board when the Dutch and UK governments began requiring their aid implementers to publish to IATI.

Developing-country governments and civil society have expressed a demand for comprehensive, timely, comparable, accessible, high-quality, reliable, and useful data about development cooperation. IATI seeks to meet that demand. One crucial piece of the information, net aid flow, is not easily captured. It is a measure of the amount of a donor's aid that is actually transferred to a country and expended in the local economy on such things as health services, classroom instruction, and agricultural research and extension services. Knowing the net flow is important for assessing whether aid is supporting developing-country governments to hold donors accountable and are being accountable themselves to their own people. Net aid flow is a reasonable proxy for similar types of aid information in which countrylevel actors are interested. The ability of these actors to access that information is a useful proxy for the ability of donor-country data producers to satisfy user demand.

In the case of Sweden, the Ministry of Foreign Affairs and the Swedish International Development Cooperation Agency (SIDA) created the Openaid.se website ${ }^{2}$ in April 2011 to help visualize when, to whom, and why Sweden has provided aid funding. Sweden has published to IATI since November 2011 and refreshes 167 datasets on the IATI website monthly-the most of any bilateral donor.

In this report we systematically capture gaps in Swedish IATI data that impede us from determining net Swedish aid flows to Tanzania. In addition to looking at general gaps, we capture gaps in the data on how much Swedish aid flows into particular sectors (such as agriculture and women's empowerment projects), at particular times, and to particular locations within Tanzania. According to SIDA, Tanzania remains Sweden's primary African partner. Between 1963 and 2015, Sweden provided a total of \$5 billion in official development assistance (ODA) to Tanzania. SIDA notes in its 2013-2019 results strategy for Tanzania that prior to 2013, Sweden contributed to:

- about 20 percent of all new rural connections to the electricity grid since 2006;

- access to financial services for about 1 million small businesses, of which more than 50 percent of the beneficiaries were women and young people;

- enhanced research capacity (about 100 students were awarded degrees);

- increased access to primary and upper secondary schools; and

- improved transparency and accountability.

Tracing Swedish Development Flows: A study of the traceability of Swedish aid to Tanzania 
This report's methodology seeks to follow the money, tracing Swedish development cooperation flows through transaction details published to IATI, from the Swedish treasury to its final end use.

\section{The distribution of Swedish development cooperation transferred to Tanzania by time period is as follows:}

- $\$ 123$ million in 2013: 50 percent of this was general budget support (GBS).

- \$53.8 million in 2014: Sweden provided no GBS in 2014. According to the Swedish Embassy in Tanzania, evidence of financial mismanagement and unfavorable audits of the Tanzanian government resulted in suspension of GBS and explain the sharp decline of Swedish ODA from its 2013 level.

- $\$ 103$ million in 2015; GBS accounted for 31.5 percent.

\section{The amount of net Swedish ODA that definitely arrived in Tanzania is as follows:}

- 77 percent (\$95 million) reached Tanzania directly in 2013, going either to the government or its agencies (67 percent) or to Tanzania-based organizations (approximately 11 percent). ${ }^{3}$

- 28 percent ( $\$ 15$ million) reached the country directly through the Tanzanian government (10 percent) and Tanzania-based organizations (18 percent) in 2014.

- 80 percent ( $\$ 82$ million) reached Tanzania through the government (66 percent) and Tanzania-based organizations (14 percent) in 2015.

Moreover, based on findings from the SIDA civil society organization (CSO) database, the implementing organizations for most of the transactions allocated to Sweden-based NGOs are local/Tanzanian organizations, and there is a high likelihood that most of the money reached Tanzania.

Nevertheless, in 2013, 1 out of every 11 krona of Swedish ODA allocated to Tanzania was completely untraceable using Openaid.se and IATI data, and 5.5 percent of the funds went to unidentified implementers.

We can verify that a high percentage of Swedish funds arrived in Tanzania and entered the government budget in 2013 and 2015, because a significant share of Swedish ODA was provided as GBS, but we know nothing about where the money went after that. Recipient government uses of development cooperation flows are outside the scope of IATI.

\section{Gender equality}

According to our analysis of the use of gender equality policy markers on Openaid.se for 20132015, Sweden reported that more than 90 percent of the funds disbursed to Tanzania had gender equality as either a principal or significant objective. These funds supported a mix of efforts to target services to meet the needs of women and girls and more transformative activities aimed at promoting women's rights and empowering women. In 2014, Sweden began implementing its feminist foreign policy, but we cannot say for certain whether this played a direct role in the high levels of aid tagged with a gender equality objective. In 2013 and 2015, a substantial portion of the aid so tagged went to the government for GBS. Sweden and other donors that provided GBS in those years consider it to have supported women's and girl's education and the creation of job opportunities for women.

We also found that most of the funds with gender equality policy markers went to projects with a "significant" gender equality objective, rather than a "principal" objective. By the Swedish government's definition, these projects would have been implemented even without the gender equality policy objective. 
The amount of Swedish development cooperation (excluding GBS) that is reported using classifications that align with Tanzanian budget classifications is as follows:

- 2013: 68 percent

- 2014: 41 percent

- 2015: 68 percent

By definition, GBS aligns with the Tanzanian budget.

\section{Swedish ODA to Tanzania by sector is as follows:}

- In 2013, 50 percent of net ODA (\$61 million) went to the government of Tanzania as GBS and 16 percent ( $\$ 19$ million) was allocated to electricity transmission and distribution.

- In 2014 , the top five sectors funded by Swedish ODA were economic and development policy planning (29 percent of net ODA), strengthening of civil society (14 percent), research and scientific institutions (12 percent), health education (8 percent), and financial policy (7 percent).

- In 2015, more than 60 percent of net ODA again went to GBS and electricity transmission and distribution.

Though the highest incidence of poverty in Tanzania is in the rural areas, where the majority of poor people depend on agriculture for their livelihoods, our analysis of Openaid.se data found that Sweden extended only a small share of ODA to agriculture. Nevertheless, the Swedish government sees good progress on its goal of helping to gradually reduce Tanzania's aid dependence by investing in agricultural markets. Though it appears that the resources that went directly to agriculture over 2013-2015 were very low, the high level of resources directed to rural electric distribution and transmission should benefit the agricultural sector indirectly through improved infrastructure.

\section{What is not captured in Swedish IATI data?}

- Swedish IATI data do not permit us to systematically determine the distribution of Swedish development cooperation transferred to Tanzania by sub-national location, as the data do not provide recipient region information.

- Using Swedish IATI data, we cannot determine whether Swedish ODA is "on budget" (that is, reported in Tanzanian budget documentation) or disbursed through Tanzanian systems. This is because the Tanzanian government does not publish data to IATI-few aid-recipient governments do so.

- It is difficult to ascertain with confidence how much Swedish development cooperation went to particular sectors.

\section{Based on this gap analysis, we offer the following policy recommendations:}

\section{Swedish IATI/Openaid.se data}

- To enable further traceability, encourage implementers of Swedish aid to publish their data to IATI and support them in doing so.

- Report recipient region information to IATI.

- Increase the consistency of ODA reports across IATI/Openaid.se and Organisation for Economic Co-operation and Development (OECD) databases.

- Improve the information provided through the titles and descriptions of projects.

- Publish the name of all implementing organizations.

- Maintain consistency in reporting the implementing organization type.

- Provide details on individual country budgets when projects involve more than one country. 
IATI

- Work on methods that would allow traceability of individual flows within activities.

- Encourage reporting organizations to use the IATI code list and report according to the IATI Standard.

- Continue to work with the Joined-up Data Alliance (JDA), which brings together open publishing standards in diverse fields, such as development cooperation and public contracting. This would potentially allow traceability across aid flows and government budgets in aid-receiving counties.

- Promote best practices to publishers with regard to aligning aid and recipient-country budget classifications.

\section{Implementers of Swedish ODA}

- Report data to IATI.

- Ensure that reports are complete and accurate. 


\section{INTRODUCTION}

"If you produce data, publish it. If you have data, use it. If you don't have data, demand it."

\section{BACKGROUND}

At High-Level Forums in Rome (2003) and Paris (2005), leaders of aid donor and recipient countries came together with development practitioners and set forth five principles to make aid more effective: country ownership, donor use of country systems, harmonization among donors, managing for results, and mutual accountability. To operationalize the last of these principles, participants in the third High-Level Forum on Aid Effectiveness, held in Accra in 2008, launched the International Aid Transparency Initiative (IATI). ${ }^{5}$ This system allows aid donors and development organizations to act on their transparency commitments. By making information about aid allocations easier to access and use, IATI aims to help governments and civil society in the developing world overcome the challenges they face in attempting to obtain that information, which is essential for effective, efficient, and accountable development planning and management. ${ }^{6}$ Aid transparency helps in four ways: it gives government officials better information to help them allocate resources; it gives civil society actors better information to help them hold government to account; it helps the multiple actors and stakeholders involved in development coordinate their activities: ${ }^{7}$ and it helps people everywhere who care about development share and learn from their experiences.

In 2011, the IATI Steering Committee agreed to the IATI Standard, which is a list of information that development cooperation organizations should publish, along with technical instructions for representing that information as structured open data in machine-readable format. As of the end of April 2018, 700 development organizations had published their data to IATI. ${ }^{8}$ Many new publishers came on board when the Dutch and UK governments began requiring grantees to publish to IATI. ${ }^{9}$ Publishers include bilateral, multilateral, and private donors (both foundations and for-profit companies). More than two-thirds of the publishers are nongovernmental organizations (NGOs) (see Figure 1).

Despite this significant donor progress on aid transparency, country-level actors still struggle to access up-to-date and reliable data on current and future development cooperation and detailed information on where, when, by whom, how, on what, and in which sectors development cooperation funds are spent. ${ }^{10}$ These actors may be unaware of IATI and how it could help meet their data needs; some IATI publishers may provide either poor-quality or incomplete reporting; and users might not have access to the right tools or the capacity to use them. ${ }^{11}$

\section{Net aid flow}

Developing-country governments and civil society have expressed a demand for comprehensive, timely, comparable, accessible, high-quality, reliable, and useful data about development cooperation. ${ }^{12}$ IATI seeks to meet that demand. One part of this, net aid flow, is a crucial piece of information that is not easily captured. It is a measure of the amount of a donor's aid that is actually transferred to a country and expended in the local economy on such things as health services, classroom instruction, or agricultural research and extension services that can boost smallholder farmers' productivity and incomes. ${ }^{13}$ Knowing the amount of net aid is important for assessing whether developing-country governments are holding donors accountable and are themselves accountable to their own people. Indeed, analyzing the ability to find a number for net aid flow is crucial to the broader discussion of aid transparency because net aid flow is a reasonable proxy for similar types of aid information in which country-level 
actors are interested. The ability of these actors to access that information is therefore a useful proxy for the ability of donor-country data producers to satisfy user demand.

\section{Figure 1: IATI publishers by organization type (\% of all publishers)}

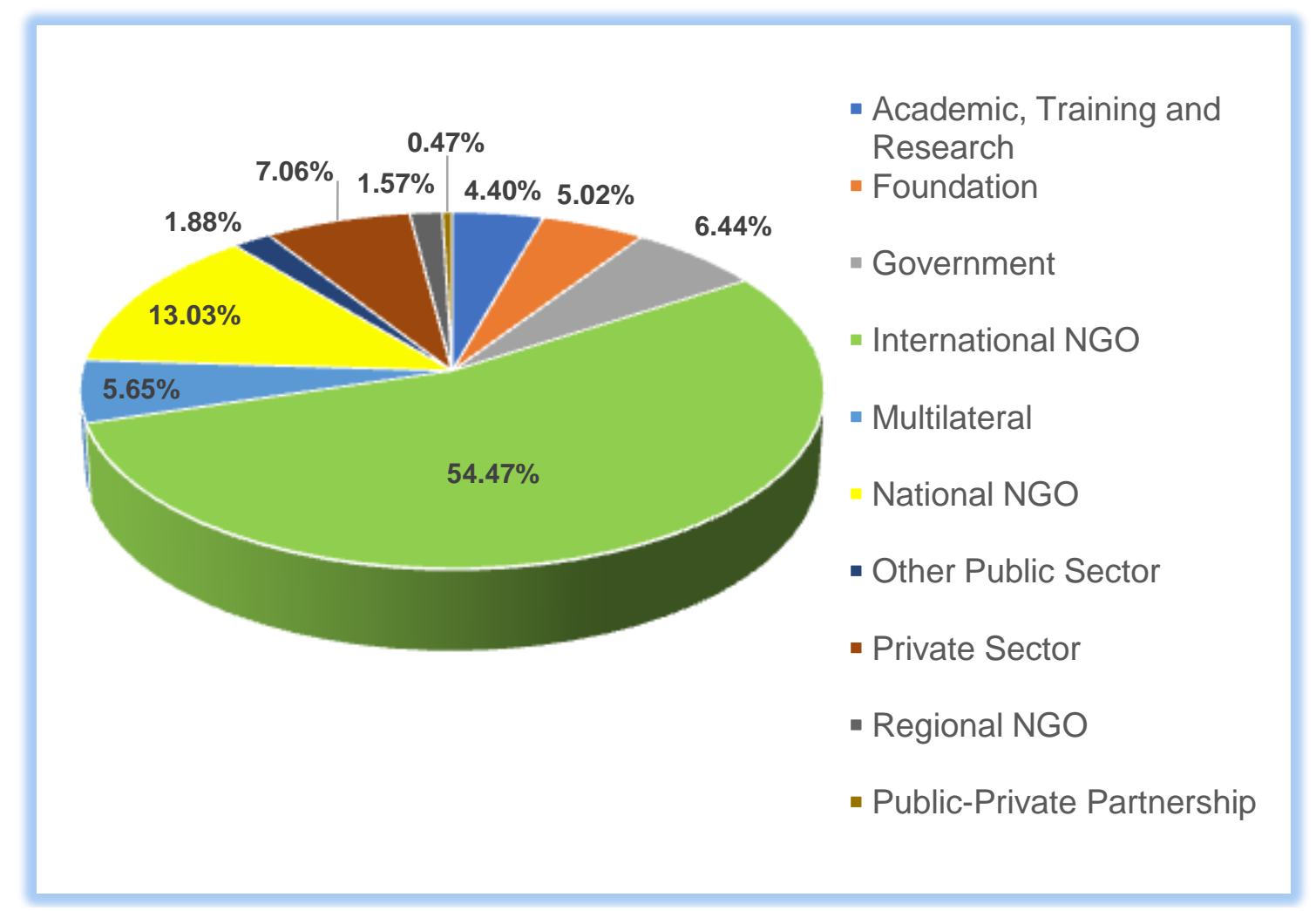

Source: IATI, January 31, 2018 data.

Net aid flows are typically far less than what donors report to IATI and the Development Assistance Committee (DAC) of the OECD. ${ }^{14}$ A significant amount of aid never actually leaves the donor country. Overhead fees and non-transferable aid are two significant costs that result in less aid for on-the-ground development. Non-transferable aid includes debt relief, imputed student costs, in-donor country refugee costs, administrative costs, interest subsidies, and indonor country promotion of development awareness.

Along with aid traceability, a related concern is whether development cooperation is "on budget" (reported in partner-country budget documentation) and disbursed using partner-country systems. When it is, this can enable management, oversight, and scrutiny by domestic constituencies (such as parliament, the media, and civil society). If flows are well managed and subject to accountability processes, they are more likely to be allocated and used efficiently. ${ }^{15}$

\section{Swedish aid transparency}

The Kingdom of Sweden, which has a long history of transparent governance, has endorsed a series of international commitments to make its aid transparent in order to promote greater aid effectiveness. In 2010, the Swedish government introduced a development cooperation reform agenda, including an Aid Transparency Guarantee. ${ }^{16}$ The government explained, "The guarantee means that all public documents and public information will be made available online. The information must explain when, to whom and why money has been made available, and what results have been achieved." ${ }^{17}$ 
In keeping with this guarantee, Sweden has published to IATI since November 2011. Each month it refreshes 167 datasets on the IATI website-the most of any bilateral donor. ${ }^{18}$

In addition, in April 2011 the Swedish Ministry of Foreign Affairs (MFA) and the Swedish International Development Cooperation Agency (SIDA) created the Openaid.se website. They update the data on the site on a monthly basis and publish it according to the IATI Standard. ${ }^{19}$ SIDA maintains that the Openaid.se data hub contributes to better results, efficiency, and accountability by providing a better basis for planning and decisions, making results more visible, strengthening conditions for accountability, and limiting possibilities for corruption. ${ }^{20}$ Most information about Swedish aid is available on Openaid.se, although the site states, "Parts of the aid information are subject to confidentiality and therefore excluded from publication on Openaid.se. This is because cooperative partners and individuals may be harmed by its publication." ${ }^{21}$

Sweden is considered one of the most transparent donors. ${ }^{22}$ SIDA and MFA together ranked ninth among 46 donors (and third among 29 bilateral donors) on Publish What You Fund's (PWYF) 2016 Aid Transparency Index. The rating improved substantially from 2013 to 2014, then declined slightly. ${ }^{23}$ PWYF notes that Sweden plays "a leading role in the IATI community" but also recommends that it "work to improve the quality and coverage of some of the items published at the activity-level, starting with planned dates, sub-national locations, and contracts." ${ }^{24}$ IATI's own assessment of its publishers, which reports on three dimensions (timeliness, forward-looking, and comprehensiveness), ranks Sweden third among all IATI publishers, after the United Nations World Food Programme and Gavi, the Vaccine Alliance. ${ }^{25}$

A study of Swedish aid transparency notes that Openaid.se provides far more information than many donors make available, including project documentation, geocoding, and results data. However, despite some improvements over time, much of the available material remains difficult for citizens in either Sweden or partner countries to use, owing to its complexity and the frequent use of technical, bureaucratic terminology. ${ }^{26}$ Some of the key materials on Openaid.se, such as progress reports on country development strategies, are available only in Swedish, which limits their accessibility to those who cannot read the language, such as most citizens of Tanzania and the authors of this report.

This report systematically captures gaps in Swedish IATI data that impede a user outside the Swedish government (such as a partner-country user) from determining the net amount of Swedish development assistance flowing to Tanzania. We selected Tanzania as the target country of the study as it is a long-time recipient of substantial Swedish aid. In addition to looking at general gaps, we capture data gaps on how much Swedish aid flows into particular sectors (such as women's empowerment projects and agriculture), at particular times, and in particular locations in Tanzania.

Our findings on the level of transparency of Swedish aid to Tanzania are intended to support Oxfam advocacy in both donor countries and Tanzania and to encourage Swedish policy makers to enhance the transparency and accountability of Swedish development cooperation. Because we are using the same methodology as in a companion study of US aid to Ghana, ${ }^{27}$ we also offer a comparative perspective on aid transparency across donors. Along with overall improvements in transparency, donors are increasingly providing more funds for women's empowerment projects, so our findings should help improve the IATI Standard on reporting on these projects.

\section{SCOPE OF THE STUDY}

Data on development flows were a key topic in discussions around the Third International Conference on Financing for Development in $2015,{ }^{28}$ and calls were made for a "data revolution" in conjunction with the launch of the Sustainable Development Goals at the UN 
General Assembly that same year. ${ }^{29}$ While there are a variety of political, bureaucratic, or technical reasons why aid providers have failed to produce necessary aid data, this study will only assess whether Sweden's IATI data for 2013-2015 can sufficiently capture the net flow of aid transferred to Tanzania. Rather than conducting a procedural political economy analysis of the reasons why information gaps exist, this study aims to provide the foundation for such an analysis by identifying those gaps. It should prove useful to advocates of both greater aid data transparency on the supply side and more effective use of aid data on the demand side.

\section{REPORT OBJECTIVES}

The objectives of this report are to:

- use Swedish IATI data to determine the net amount of Swedish development cooperation transferred to Tanzania during 2013-2015;

- identify specific gaps and limitations in Swedish IATI data that hinder the calculation of net flows to Tanzania; and

- make clear policy recommendations for Swedish officials and the IATI Technical Advisory Group for closing the identified gaps.

\section{RESEARCH QUESTIONS}

1. Based on available IATI data, what amount of Swedish development cooperation was actually transferred to Tanzania in 2013, 2014, and 2015?

a. Is it possible to find out the net amount of Swedish assistance transferred to Tanzania in those years? What information gaps need to be filled in order to find out how much net Swedish assistance was transferred to Tanzania?

b. What is the amount of Swedish development cooperation expended in the Tanzanian economy?

c. What is the amount of non-transferable aid?

d. What is the amount of Swedish development cooperation provided to nonSwedish versus Sweden-based voluntary organizations and contractors?

e. What is the amount of Swedish development cooperation that is "on budget"reported in Tanzanian budget documentation-and disbursed using Tanzanian systems?

f. What is the amount of Swedish development cooperation that is reported using classifications that align with Tanzanian budget classifications?

2. What factors account for the gaps in information that prohibit an end user from knowing how much net aid is transferred to Tanzania? Are these information gaps the result of a limitation in Swedish compliance with the IATI commitment, a limitation of the IATI Standard to capture the right information, or some other factor(s)?

3. Based on available IATI data, what is the distribution of Swedish development cooperation transferred to Tanzania by sub-national location, sector, and time period?

5. Based on available IATI data, what is the net amount of Swedish assistance transferred to Tanzania in 2013, 2014, and 2015 that is for women's empowerment projects? 


\section{RESEARCH METHODS}

We use IATI data on Swedish aid to Tanzania to trace flows from the Swedish treasury as far as possible along the implementation chain. We employ the methodology developed by the late Simon Parish of Development Initiatives (DI $)^{30}$ for an earlier DI-Oxfam collaboration on tracing US aid flows to Ghana. ${ }^{31}$

The methodology is based on traceability of development cooperation flows-i.e., following the money through transaction details published to IATI. The core unit of analysis within IATI is an activity. ${ }^{32}$ Typically, country aid programs comprise a number of activities. Reports to IATI about an activity include details of all incoming and outgoing financial transactions. Each transaction has a unique identifier and contains data covering (among other things) the date; the value; a description; details about the provider and receivers of the funds; and classification as disbursement, expenditure, or incoming funds. So, if each organization providing and receiving aid money published this information along with the identifier of the activity that it is funding, it would be possible to follow the money to its final expenditure on goods and services. 


\section{TRACING SWEDISH AID TO TANZANIA USING IATI DATA}

\section{PRE-2013 SWEDISH AID}

The United Republic of Tanzania is one of Sweden's long-standing partners in development cooperation, with a relationship dating back more than half a century, to $1963 .{ }^{33}$ SwedenTanzania development cooperation has engaged all sectors of Tanzanian society, from agriculture, education, health, and the environment to energy, infrastructure, the private sector, and budget support to the Tanzanian government. According to SIDA, Tanzania remains Sweden's primary partner in Africa in terms of aid volume. ${ }^{34}$ Data from OECD.Stat ${ }^{35}$ show that Sweden provided a total of $\$ 5$ billion in official development assistance (ODA) to Tanzania over 1963-2015. In 2015, Sweden ranked as the seventh-largest donor to Tanzania. ${ }^{36}$

The Swedish government notes that its pre-2013 development cooperation strategy for Tanzania had a number of important positive results, contributing to:

- about 20 percent of all new rural connections to the electricity grid since 2006;

- access to financial service for about 1 million small businesses, of which more than 50 percent of the beneficiaries were women and young people;

- enhanced research capacity (about 100 students were awarded degrees);

- increased access to primary and upper secondary schools; and

- improved transparency and accountability. ${ }^{37}$

\section{SWEDISH AID TO TANZANIA, 2013-2015}

The Swedish government adopted a new strategy for Swedish support to Tanzania during 20132019. This strategy is intended to contribute to sustainable growth and poverty alleviation, with a special focus on women, children, and young people. According to an Openaid.se report, ${ }^{38}$ the strategy involves a maximum of 5.5 billion Swedish krona (SEK) (equivalent to $\$ 0.6$ billion) in ODA to help provide low-income Tanzanians better opportunities to support themselves through employment and entrepreneurship. The primary goal of the strategy is to gradually reduce Tanzania's aid dependence by investing in agricultural markets, sustainable energy, education, and business. However, in 2013-2015, our analysis of Openaid.se data found that only an insignificant amount of Swedish ODA went directly to agricultural development. Therefore there is little evidence of meeting the goal of reducing Tanzania's aid dependency through investing in the agricultural sector; we discuss this in more detail later in the report.

In 2013 Sweden provided $\$ 123$ million in ODA to Tanzania, the second-highest amount, after the peak of 2008, that Sweden had allocated to the country since the early 1990s (Figure 2). This is also the second-highest recorded level of Swedish ODA to any country reported to IATI/Openaid.se for the period 1998-2015. About half of this amount went to the government of Tanzania as general budget support (GBS). The following year, Sweden extended a total of $\$ 54$ million in ODA to Tanzania, the lowest amount of aid since 2000. This represented a decrease of 56 percent, while globally, Swedish ODA rose slightly from $\$ 5.4$ billion to $\$ 5.5$ billion. ${ }^{39}$ Figure 3 
reveals that between 1998 and 2015, Tanzania was the top recipient of Swedish ODA, but in 2014 it fell out of the group of five leading recipients owing to the sharp reduction in aid that year. ${ }^{40}$

According to Openaid.se data, evidence of financial mismanagement and unfavorable audits of the Tanzanian government in 2013 explain the sharp decline of Swedish ODA in 2014.

According to Openaid.se data, a study carried out on in-depth financial audits in Tanzania, approved in October 2013, revealed that poor accounting practices and inaccurate financial reporting were among the factors that resulted in a suspension of partner funds. ${ }^{41}$ The Swedish Embassy in Tanzania confirmed to us that the 2014 cutoff of GBS was due to this so-called IPTL (for Independent Power Tanzania, Ltd.) scandal. ${ }^{42}$ An article in the Guardian reported that the donors that provided GBS to Tanzania, including Sweden, suspended $\$ 500$ million in aid following reports of corruption. The scandal involved allegations of financial crimes on the part of senior Tanzanian officials in connection with the electricity sector (which had also received project support from Sweden). ${ }^{43}$ In 2015, Sweden extended $\$ 103$ million in ODA to Tanzania, an increase of 48 percent over the preceding year, but still below the 2013 level.

During 2013-2015, SIDA provided the overwhelming majority of Swedish aid to Tanzania. (See Box 1 of Appendix B for a complete list of Swedish government agencies that reported on Openaid.se as transaction provider organizations to Tanzania.)

In 2013 and 2015, the main uses of Swedish ODA, as reported in Openaid.se/IATI, were GBS provided to the Tanzanian government (50 percent of Swedish ODA in 2013 and 32 percent in 2015) and project-type interventions (22 percent of Swedish ODA in 2013 and 39 percent in 2015) (Figure 4). SIDA provided both types of aid (see Appendix A for more detail on the aid-type codes used in the figure). The category of aid types across extending and implementing organizations appears in Figure 5. In 2014, project-type interventions (35 percent of ODA) and contributions to specific purpose programs and funds (30 percent of ODA) account for the majority of Swedish ODA to Tanzania. Compared with GBS, these aid modalities give donors more control over the money provided and avoid the problems with unfavorable audits. There is a risk, however, that the aid provided this way will align less well with country development plans.

Figure 2: Swedish aid to Tanzania, 1963-2015 (\$ million)

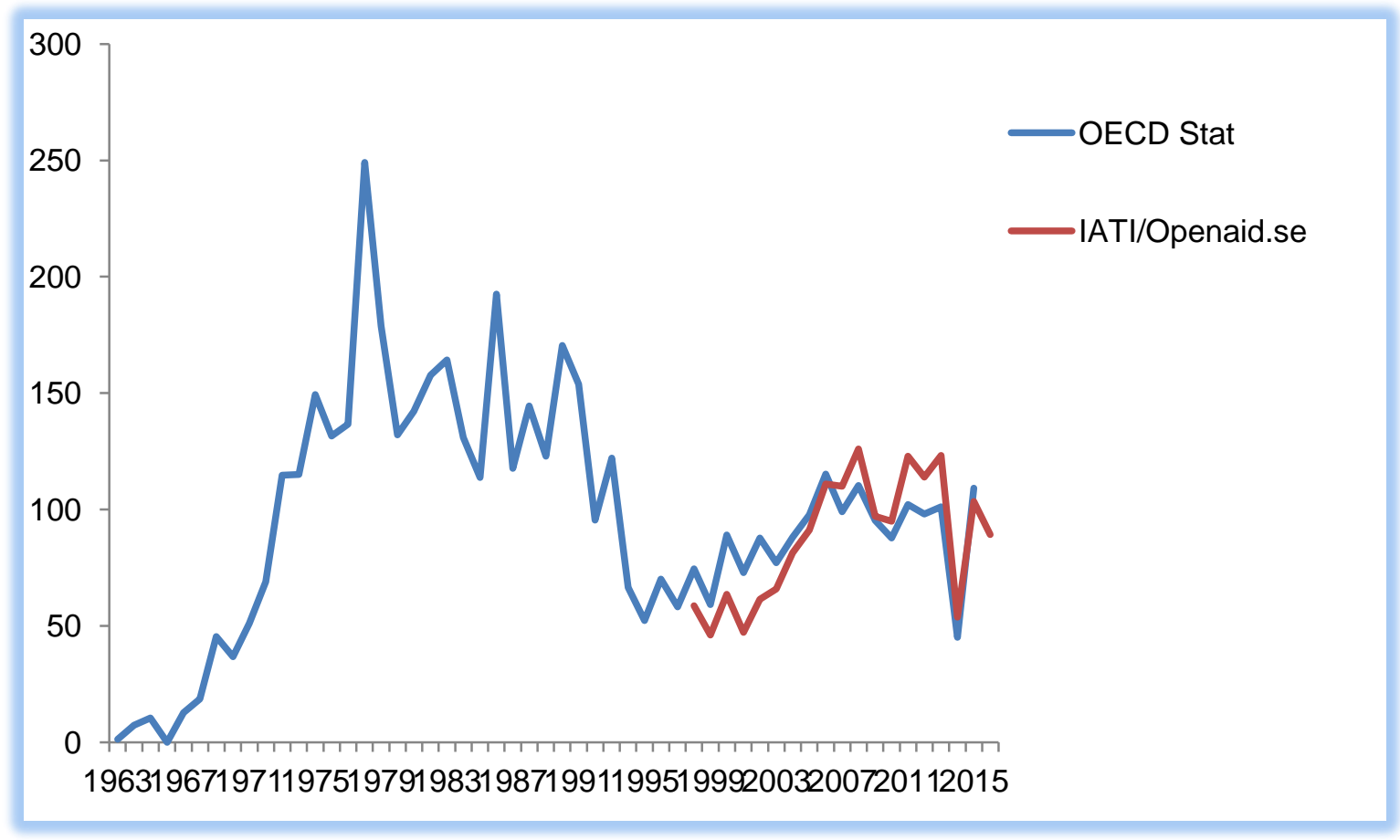

Sources: OECD.Stat and IATI data.

Within project-type interventions, electricity transmission and distribution was the most common type of project, accounting for 43 percent and 80 percent of total project-type interventions in 
2013 and 2015, respectively (Figure 6). The electricity transmission and distribution project involved construction of the Makambako-Songea transmission and distribution line to provide access to reliable and affordable electricity in six districts in the Iringa and Ruvuma regions of southern Tanzania. More than 40 percent of the project-type aid went to the health, education, and democratic participation/civil society sectors in 2014. Openaid.se data show that agricultural project interventions accounted for a negligible share of aid in all three years, even though agricultural development was one of the main goals of SIDA's development cooperation strategy for Tanzania.

\section{Figure 3: Top 10 recipients of Swedish aid by amount allocated, 1998-2015}

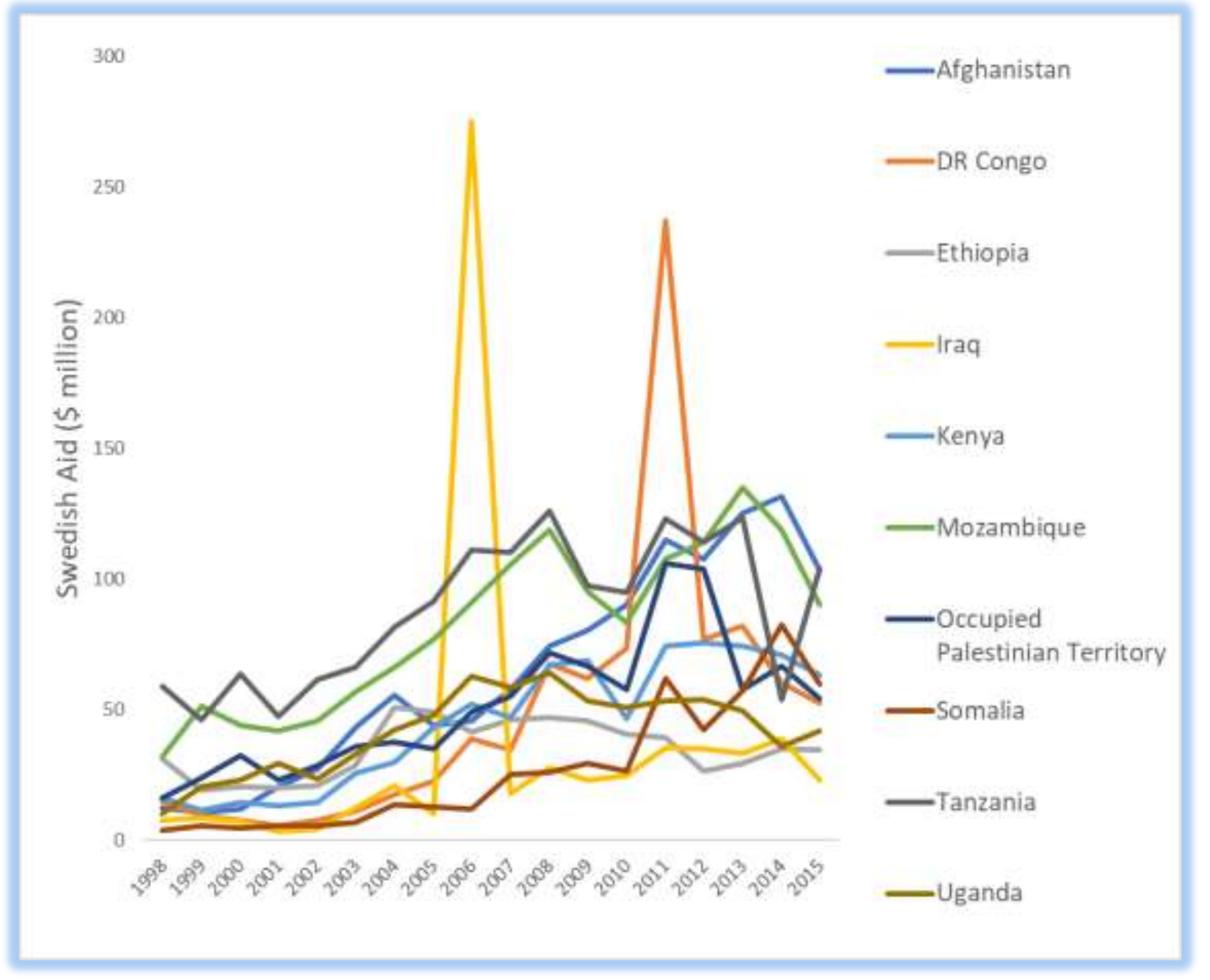

Source: IATI data.

\section{NET ODA}

Subtracting the non-transferable ${ }^{44}$ aid (well below 0.1 percent of Swedish ODA to Tanzania) from total ODA, net Swedish ODA extended to Tanzania was $\$ 122.9$ million in 2013, $\$ 53$ million in 2014, and \$102 million in 2015.

In Openaid.se data, costs related to refugees in Sweden are already deducted from the aid budget, although those costs are considered ODA by the DAC. The costs of hosting refugees in Sweden increased by more than 200 percent between 2013 and 2015, from $\$ 705$ million to $\$ 2.4$ billion. But total Swedish ODA (exclusive of these costs) increased by only 20 percent, from $\$ 5.4$ billion to $\$ 6.5$ billion. This disparity likely resulted from the humanitarian crisis in the Middle East, Sweden's willingness to accept refugees (as compared with some other European countries), ${ }^{45}$ 
and the partial funding of hosting refugees in Sweden from reductions in planned development cooperation spending. ${ }^{46}$ According to the UN Refugee Agency (UNHCR), at the end of 2016, Sweden hosted 349,303 refugees, asylum seekers, and other "persons of concern." It is important to note that at the same time, Tanzania, a low-income country, hosted $458,828 .{ }^{47}$

During 2013-2015, IATI data show that SIDA alone accounted for almost all (97 percent) of net Swedish aid to Tanzania. The Tanzanian government was the top recipient of net Swedish ODA allocated to the country in 2013 and 2015, receiving 63 percent of the funds. In 2014, the United Nations Development Programme (UNDP) was the top recipient of net Swedish ODA allocated to Tanzania, receiving 29 percent of the total provided (Figure 7).

Some of the activities covered in our analysis of Swedish aid to Tanzania during 2013-2015 continued beyond 2015. More detail on this appears in Appendix C.

Figure 4: Swedish aid to Tanzania by aid type, 2013-2015 (\%)

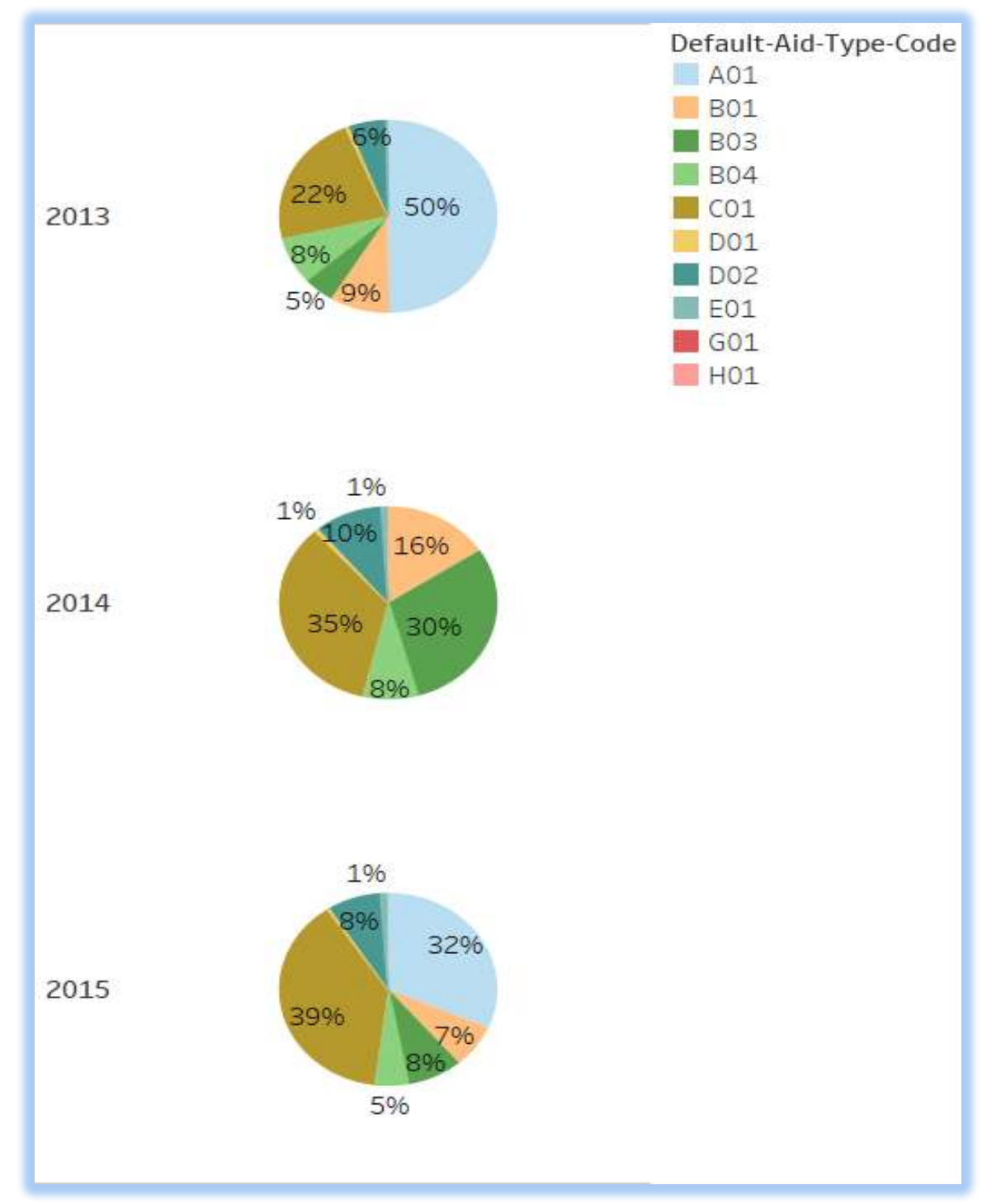

Source: IATI data.

Notes: Totals each year may not add to 100 percent due to rounding.

$\mathrm{A} 01=$ general budget support, $\mathrm{B} 01=$ core support to NGOs, other private bodies, public-private partnerships, and research institutes, B03 = contribution to specific purpose programs and funds managed by international organizations, B04 = basket funds/pooled funding, C01 = project-type interventions, D01 = donor country personnel, D02 = other technical assistance, E01 = scholarships/training in donor country, G01 = administrative costs not included elsewhere, $\mathrm{H} 01$ = development awareness. 
Figure 5: Swedish aid to Tanzania by extending and implementing organization, 20132015 (\$ million)

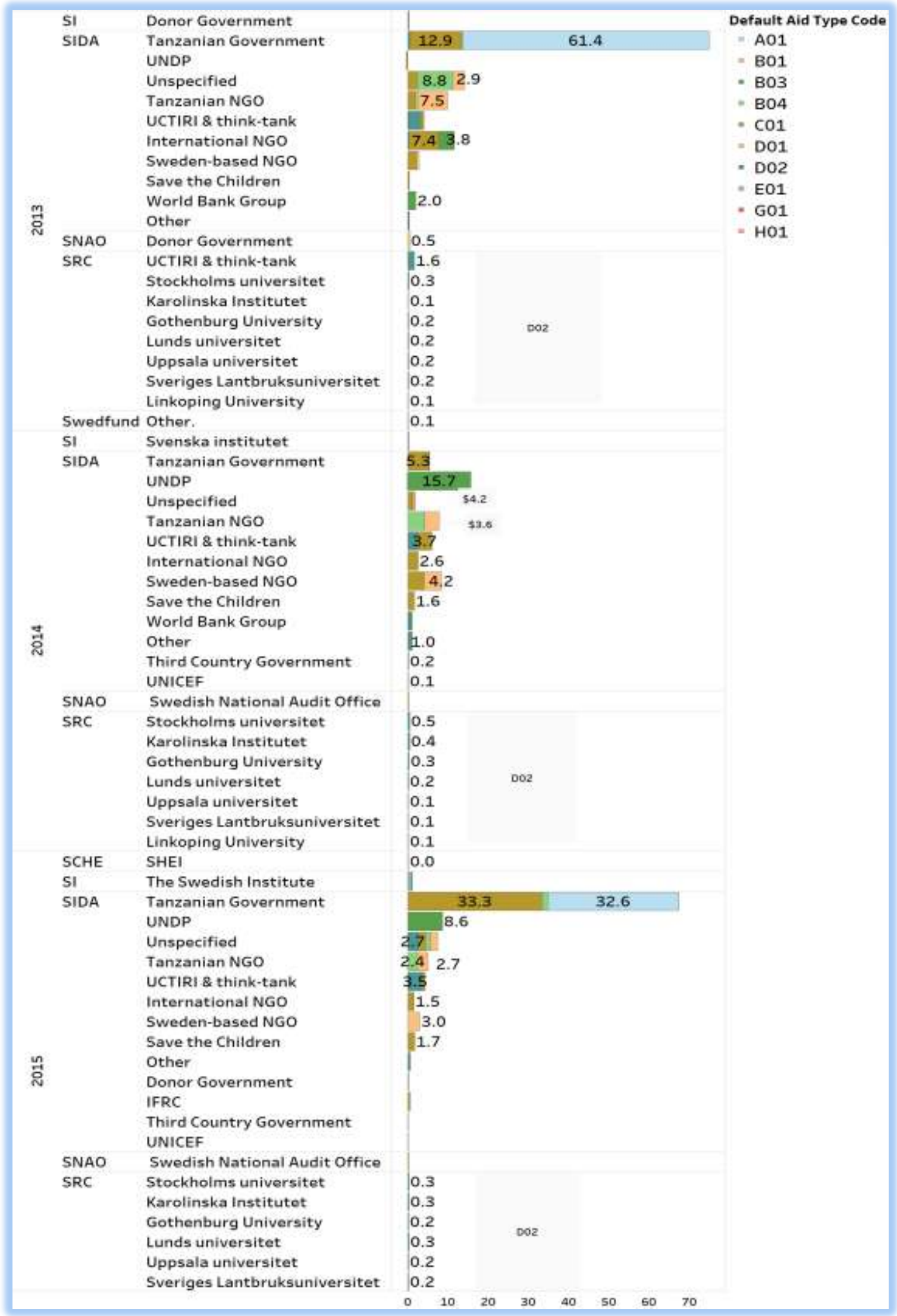

Source: IATI data. Note: UCTIRI = University/college/other teaching institution/research institute. IFRC = International Federation of Red Cross and Red Crescent Societies. 
Figure 6: Sectoral distribution of Swedish project aid to Tanzania, 2013-2015 (\%)

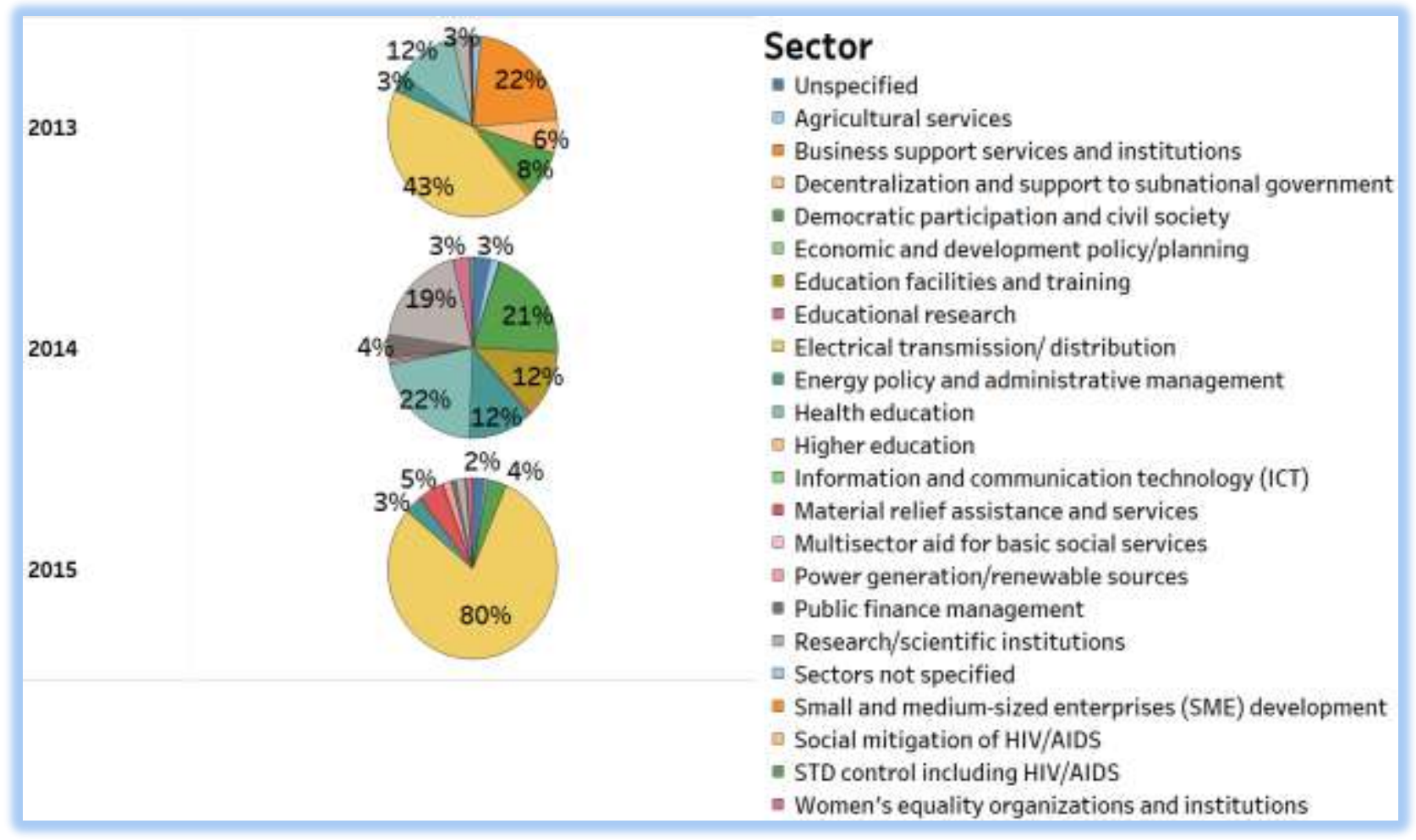

Source: IATI data.

\section{HOW MUCH AID ARRIVED IN TANZANIA IN 2013?}

Table 1 summarizes our analysis of Swedish IATI data to determine how much net Swedish ODA arrived in Tanzania during 2013-2015. For 2013, we found that 67 percent ( $\$ 82$ million) of net Swedish ODA arrived in Tanzania and went directly to the national government. Another approximately 11 percent ( $\$ 13$ million) went to Tanzanian NGOs. ${ }^{48}$ See Box 2 of Appendix B for more detail on these entities. It is important to note that we have no way of knowing from IATI or Openaid.se how the money was used once it reached Tanzania or whether any of it flowed back out of the country to external consultants or other implementers further down the chain. We cannot verify that the remaining 23 percent of net Swedish ODA actually reached Tanzania, because data published on Openaid.se are incomplete and IATI reporting by receiving organizations is incomplete or nonexistent.

We found that 2 percent of the net ODA (\$2 million) went to three specified international organizations (intergovernmental and nongovernmental) with country offices in Tanzania: ${ }^{49}$ the World Bank, UNDP, and Save the Children Sweden. ${ }^{50}$ Though UNDP and the World Bank ${ }^{51}$ have published their data to IATI, they have not yet reported the transactions from SIDA allocated to Tanzania, so we cannot be completely certain that the two organizations spent all or even any of the money in Tanzania, however likely that may be. Save the Children Sweden does not presently publish to IATI. 
Figure 7: Net Swedish aid to Tanzania by implementing organization, 2013-2015 (\%)

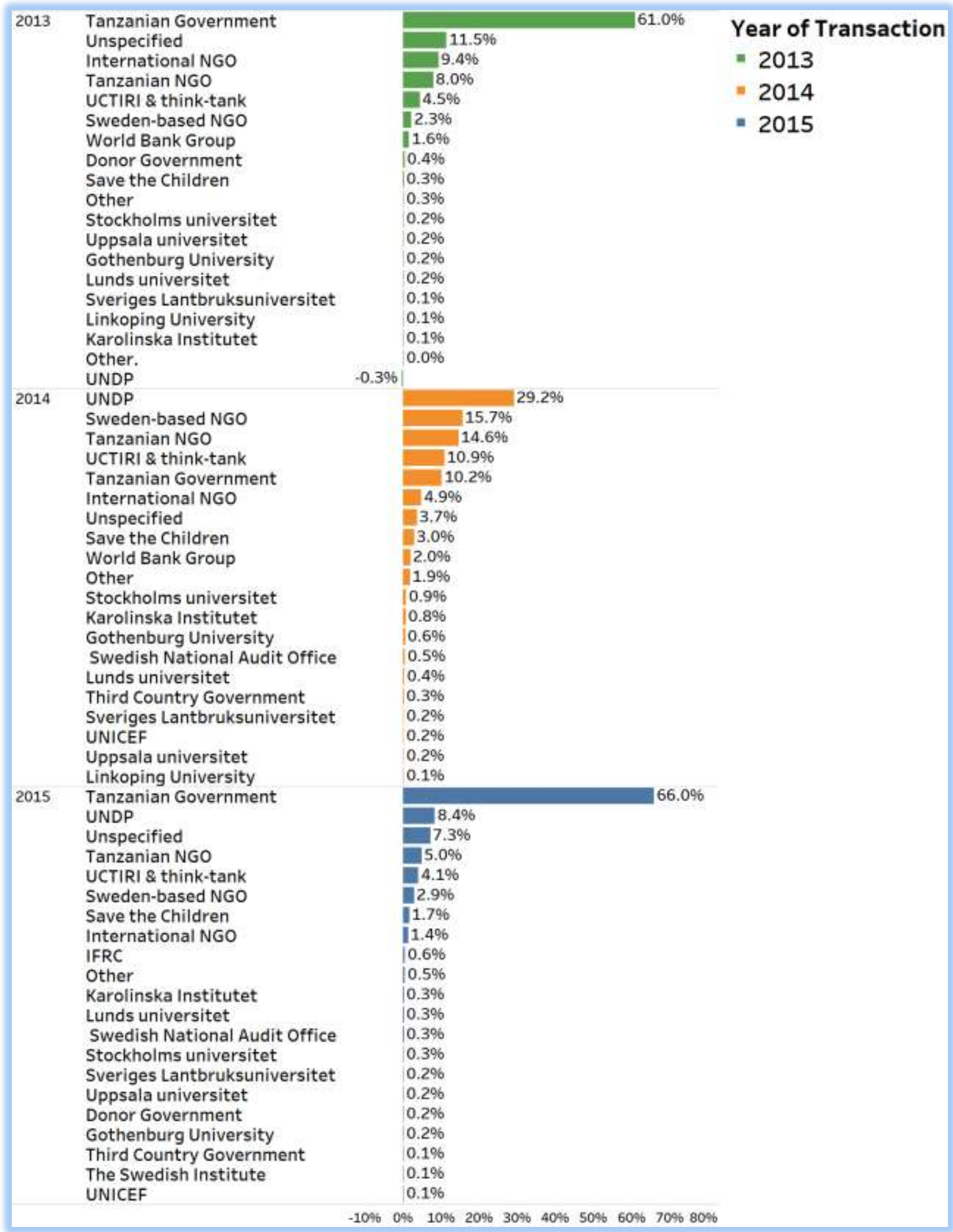

Source: IATI data. 
An additional 12 percent of net Swedish ODA allocated to Tanzania (\$15 million) went to international NGOs. ${ }^{52}$ We were able to verify that five out of the seven organizations have country offices in Tanzania: ${ }^{53}$ Restless Development, Twaweza, the African Medical and Research Foundation (AMREF Tanzania), the Africa Enterprise Challenge Fund (AECF), Trade and Markets East Africa (TMEA, now known as TradeMark East Africa), and the Hanns R. Neumann Stiftung (HRNS). ${ }^{54}$ It seems likely that at least some of the funds reached Tanzania. However, among these NGOs only Twaweza and Restless Development have published their data to IATI. Since the others have not done so, we cannot be certain whether the transactions reached Tanzania or remained at the organizations' headquarters, either in full or in part.

Twaweza is an international NGO working in Kenya, Tanzania, and Uganda. It is headquartered in Tanzania and its founding executive director is Tanzanian, but until 2014 it was a project of the Dutch NGO Hivos. It is very positive that this small organization, with a budget of just $\$ 14$ million in 2015, publishes to IATI. ${ }^{55}$ However, Twaweza could make some improvements in its reporting: it presently does not report incoming funds, flow type (for 2015 data), or the transaction provider organization, ${ }^{56}$ all of which are essential to trace ODA flows from Sweden to their end use in Tanzania. Twaweza reported a total of $\$ 42$ million in expenditure transactions allocated to Tanzania in 2013, 2014, and 2015 (\$14 million each year), but we cannot determine how much, if any, of the funds going to Tanzania came from Sweden.

During 2013-2014, Restless Development reported a total of 2.8 billion Tanzanian shillings (equivalent to $\$ 1.3$ million) in incoming funds intended for Tanzania, of which SIDA provided 45 percent. During this period, Restless Development also reported a \$1.6 million expenditure transaction to itself. The organization indicated that all the flow types, including the incoming funds from donor-government agencies that should be treated as ODA, were private grants. This appears to be simply a case of miscoding. IATI describes private grants as contributions made by NGOs and other civil society organizations, such as philanthropic foundations, based in the reporting DAC country. The activity identifier reported by Restless Development also did not match the one used in Openaid.se data. It is not possible from the IATI data to conclude for certain that the SIDA contribution is included in the \$1 million that the NGO granted to Tanzania, although that conclusion does seem reasonable. ${ }^{57}$ The use of Tanzanian currency may suggest that all of the SIDA funds were spent in Tanzania, but we cannot verify this using IATI data.

The remainder of the net ODA was allocated as follows:

- Swedish universities: 1 percent of net Swedish ODA allocated to Tanzania ${ }^{58}$

- Sweden-based NGOs (see Box 3 of Appendix B): 2 percent ${ }^{59}$

- Swedish government: 0.4 percent

- Unidentified academic and research institutions: 5 percent $^{60}$

- Unspecified: 0.5 percent $^{61}$

None of the specified recipients in Sweden have published data to IATI. However, it might be possible to further trace the use of the funds by contacting the organizations or SIDA. With regard to the unspecified recipients, it is not possible to identify the implementing agencies, trace the funds any further, or ascertain whether the money actually arrived in Tanzania.

In sum, 77 percent (\$95 million) of net Swedish ODA reached Tanzania directly in 2013, going either to the government or its agencies, mainly for GBS, or to Tanzanian organizations. Moreover, 14 percent ( $\$ 17$ million) went to intergovernmental organizations and international NGOs with country offices in Tanzania, but we cannot tell for certain how much of the flow (if any) reached Tanzania or remained at the organizations' headquarters outside the country. For the remaining 9 percent ( $\$ 11$ million), it is simply not possible to tell whether or how much of the flow reached Tanzania using Openaid.se or IATI data. In other words, 1 out of every 11 Swedish krona of Swedish ODA allocated to Tanzania is completely untraceable using Openaid.se and IATI data, and 5.5 percent of the funds went to unidentified implementers. 
Table 1: Summary of Swedish ODA to Tanzania, 2013-2015

\begin{tabular}{|c|c|c|c|c|}
\hline \multirow[t]{2}{*}{ Category } & \multicolumn{3}{|c|}{ Volume (\$) \& share (\%) of net ODA } & \multirow[t]{2}{*}{ Notes } \\
\hline & 2013 & 2014 & 2015 & \\
\hline $\begin{array}{l}\text { Total Swedish ODA } \\
\text { allocated to Tanzania }\end{array}$ & $\$ 123.0$ million & $\begin{array}{l}\$ 53.8 \\
\text { million }\end{array}$ & $\begin{array}{l}\$ 103.0 \\
\text { million }\end{array}$ & $\begin{array}{l}\text { Sum of all ODA "disbursement" } \\
\text { transactions }\end{array}$ \\
\hline $\begin{array}{l}\text { Amount of non- } \\
\text { transferable aid }\end{array}$ & $\begin{array}{l}\$ 0.3 \text { million } \\
\text { (about } 0.2 \% \text { of } \\
\text { total ODA) }\end{array}$ & $\begin{array}{l}\$ 0.5 \\
\text { million } \\
(1 \% \text { of } \\
\text { total } \\
\text { ODA })\end{array}$ & $\begin{array}{l}\$ 1.0 \\
\text { million } \\
(1 \% \text { of } \\
\text { total } \\
\text { ODA })\end{array}$ & $\begin{array}{l}\text { Sum of funds for } \\
\text { scholarships/training and } \\
\text { development awareness in the } \\
\text { donor country ( } 2013 \text { and } 2014) \text {; } \\
\text { funds for scholarships/training } \\
\text { in donor country (2015) }\end{array}$ \\
\hline Net ODA & $\$ 122.7$ million & $\begin{array}{l}\$ 53.3 \\
\text { million }\end{array}$ & $\begin{array}{l}\$ 102.0 \\
\text { million }\end{array}$ & $\begin{array}{l}\text { Subtract non-transferable aid } \\
\text { from total ODA }\end{array}$ \\
\hline \multirow[t]{2}{*}{$\begin{array}{l}\text { Direct flows to } \\
\text { Tanzania }\end{array}$} & $\begin{array}{l}\$ 82.0 \text { million } \\
(67 \% \text { of net } \\
\text { ODA })\end{array}$ & $\begin{array}{l}\$ 5.5 \\
\text { million } \\
(10 \%)\end{array}$ & $\begin{array}{l}\$ 68.0 \\
\text { million } \\
(66 \%)\end{array}$ & $\begin{array}{l}\text { Provided to the government of } \\
\text { Tanzania }\end{array}$ \\
\hline & $\begin{array}{l}\$ 13.0 \text { million } \\
(11 \%)\end{array}$ & $\begin{array}{l}\$ 9.5 \\
\text { million } \\
(18 \%)\end{array}$ & $\begin{array}{l}\$ 14.0 \\
\text { million } \\
(14 \%)\end{array}$ & $\begin{array}{l}\text { Provided to Tanzanian } \\
\text { organizations }\end{array}$ \\
\hline \multirow[t]{2}{*}{$\begin{array}{l}\text { Indirect flows to } \\
\text { Tanzania }\end{array}$} & $\begin{array}{l}\$ 2.0 \text { million } \\
(2 \%)\end{array}$ & $\begin{array}{l}\$ 18.0 \\
\text { million } \\
(34 \%)\end{array}$ & $\begin{array}{l}\$ 11.0 \\
\text { million } \\
(11 \%)\end{array}$ & $\begin{array}{l}\text { Provided to international } \\
\text { organizations with country } \\
\text { offices in Tanzania (World } \\
\text { Bank, UNDP, and Save the } \\
\text { Children Sweden) } \\
\text { Though the first two } \\
\text { organizations published data to } \\
\text { IATI, their data do not specify } \\
\text { incoming funds from Sweden } \\
\text { and where the money was } \\
\text { spent. }\end{array}$ \\
\hline & $\begin{array}{l}\$ 15.0 \text { million } \\
(12 \%)\end{array}$ & $\begin{array}{l}\$ 4.0 \\
\text { million } \\
(7 \%)\end{array}$ & $\begin{array}{l}\$ 3.0 \\
\text { million } \\
(3 \%)\end{array}$ & $\begin{array}{l}\text { Provided to unspecified } \\
\text { international NGOs. We were } \\
\text { able to identify the } \\
\text { implementing organizations' } \\
\text { names based on the } \\
\text { title/description of the projects, } \\
\text { but it is not possible to verify } \\
\text { from IATI or Openaid.se how } \\
\text { much of the money they } \\
\text { actually spent in Tanzania. }\end{array}$ \\
\hline $\begin{array}{l}\text { Indirect flows to } \\
\text { Tanzania, through } \\
\text { non-country } \\
\text { implementer } \\
\text { organizations }\end{array}$ & $\begin{array}{l}\$ 5.0 \text { million } \\
(3.5 \%)\end{array}$ & $\begin{array}{l}\$ 10.0 \\
\text { million } \\
(19 \%)\end{array}$ & $\begin{array}{l}\$ 5.0 \\
\text { million } \\
(5 \%)\end{array}$ & $\begin{array}{l}\text { Funds to Sweden-based } \\
\text { organizations (Swedish } \\
\text { universities, Swedish National } \\
\text { Audit Office, Sweden-based } \\
\text { NGOs) and third-country } \\
\text { governments (delegated } \\
\text { cooperation }^{62} \text { ) }\end{array}$ \\
\hline "Other" & $\begin{array}{l}\$ 6.0 \text { million } \\
(5.5 \%)\end{array}$ & & & $\begin{array}{l}\text { Recipient organization is not } \\
\text { specified. We do not know } \\
\text { where the money went or where } \\
\text { it was spent. }\end{array}$ \\
\hline
\end{tabular}

Source: IATI data. 


\section{HOW MUCH AID ARRIVED IN TANZANIA IN 2014?}

Based on our analysis of 2014 Swedish IATI data, we found that 28 percent ( $\$ 15$ million) of net Swedish ODA reached the country directly through Tanzania-based organizations, of which 37 percent ( $\$ 5.5$ million) went directly to the government of Tanzania.

Another 41 percent (\$22 million) of net ODA went to Tanzania indirectly through intergovernmental organizations ${ }^{63}$ and international NGOs ${ }^{64}$ that have country offices in Tanzania, but we cannot definitively determine how much of the flow reached Tanzania or remained at the organizations' headquarters.

Nineteen percent ( $\$ 10$ million) of net ODA went to Swedish organizations (universities, NGOs, and government institutes). The remaining 12 percent (\$7 million) of net ODA went to a "university, college or other teaching institution, research institute or think tank" for evaluation studies and research cooperation between Sweden and Tanzania. There is a high possibility that at least some of these funds arrived in Tanzania since these projects supported Tanzanian universities and parastatal agencies. However, we could not identify the implementing organizations for some of these flows, so it is difficult to determine for certain whether or how much of the money reached Tanzania. There is no possibility of tracing the money any further because the implementing organizations are unspecified and there is a lack of data published to IATI.

\section{HOW MUCH AID ARRIVED IN TANZANIA IN 2015?}

Our analysis of Swedish IATI data shows that in 2015 about 80 percent of net ODA ( $\$ 82$ million) definitely arrived in Tanzania through the government of Tanzania (66 percent) and Tanzaniabased NGOs ${ }^{65}$ (14 percent).

In addition, 14 percent of net ODA went to international organizations and international NGOs with country offices in Tanzania. ${ }^{66}$ Because not all of these organizations reported data on the transactions received from Sweden to IATI, ${ }^{67}$ it is impossible to trace all of these flows further to determine whether they reached Tanzania in full or in part or remained at the organizations' headquarters. Another 5 percent of net ODA went to Sweden-based organizations that have not published data to IATI; 1 percent went to unspecified organizations, so it is not possible to determine where the money was spent.

\section{CIVIL SOCIETY ORGANIZATION DATABASE}

SIDA's CSO database ${ }^{68}$ contains information on global activities implemented by Swedish civil society organizations (CSOs) with support from SIDA. SIDA has agreements with Swedish Framework Organizations, which report their activities directly to the CSO database. Framework Organizations receive funds from SIDA to carry out development programs, and SIDA permits these organizations to make grants to NGOs in developing countries. ${ }^{69}$

SIDA requires Framework Organizations to cofinance at least 10 percent of the total project budget. The CSO database only shows SIDA's financial contributions. ${ }^{70}$ In the case of Tanzania, the activities in the database are implemented mainly by Tanzanian partner organizations, with a small part of the budget going to the Swedish organizations' implementing costs (see Table 2; more information on the CSOs in the table can be found in Appendix B, Box 3). ${ }^{71}$ 
Table 2: Comparison of IATI/Openaid.se data and SIDA's CSO database by implementer $(\$ \text { million })^{72}$

\begin{tabular}{|c|c|c|c|c|c|c|}
\hline \multirow[t]{2}{*}{ Organization } & \multicolumn{3}{|c|}{ IATI/Openaid.se } & \multicolumn{3}{|c|}{ CSO database } \\
\hline & 2013 & 2014 & 2015 & 2013 & 2014 & 2015 \\
\hline Diakonia & 0.07 & & & 0.06 & 0.36 & 0.26 \\
\hline Forum Syd & 1.43 & 2.10 & 0.45 & 0.69 & 0.55 & 0.40 \\
\hline MyRight & & 0.50 & 0.35 & 0.51 & 0.46 & 0.42 \\
\hline PMU & -0.003 & 0.42 & 0.18 & 0.42 & 0.29 & 0.15 \\
\hline Church of Sweden & 0.19 & & & 0.34 & & \\
\hline Sweden Mission Council & 0.10 & 0.05 & 0.09 & 0.09 & 0.04 & 0.10 \\
\hline SSNC & 0.24 & 0.19 & 0.14 & 0.08 & 0.08 & 0.08 \\
\hline LO-TCO Secretariat & -0.0003 & & & 0.04 & 4.47 & 3.78 \\
\hline We Effect & & 1.05 & 0.55 & 0.68 & 0.83 & 0.67 \\
\hline $\begin{array}{l}\text { World Wide Fund for Nature } \\
\text { (WWF) }\end{array}$ & & 1.39 & 1.24 & 0.88 & 0.87 & 0.69 \\
\hline $\begin{array}{l}\text { RFSU TZ Men as equal } \\
\text { partner }\end{array}$ & 0.76 & 2.69 & & & & \\
\hline $\begin{array}{l}\text { Total ODA to Sweden-based } \\
\text { NGOs }\end{array}$ & $\begin{array}{l}2.8 \\
(2 \% \text { of total } \\
\text { ODA })^{73}\end{array}$ & $\begin{array}{l}8.39 \\
(15 \% \text { of } \\
\text { total ODA })\end{array}$ & $\begin{array}{l}3 \\
(3 \% \text { of } \\
\text { total } \\
\text { ODA })^{74}\end{array}$ & 3.76 & $7.94^{*}$ & $6.53^{*}$ \\
\hline
\end{tabular}

Source: IATI/Openaid.se data and SIDA CSO database.

Note: A blank cell in the table indicates no data reported for the year in question.

* The total budget in the CSO database shows $\$ 7$ million for 2014 and 2015. According to the CSO database, some of the transactions may not be presented in the list (at the activity level) but are included in the total budget.

We used the CSO database to trace the SIDA funds that went to Sweden-based NGOs in 2013, 2014, and 2015. All Sweden-based NGOs that received funds from SIDA in the IATI/Openaid.se datasets are reported in the CSO database. However, because the standards of the IATI/Openaid.se and CSO databases are quite different, it is difficult to match the transactions. The disbursement amounts are also different across the databases (see Table 2). In the CSO database, all the funds were core contributions (B01) whereas in Openaid.se some of the funds were project-type interventions in 2013 and 2014. We also attempted to use common project start and end dates as a way to match projects across the two databases, but that approach is problematic as well. In any event, the implementing organizations for most of the transactions are local or Tanzanian organizations, so it is extremely likely that at least some of the funds provided to Swedish Framework Organizations reached Tanzania (Figure 8). 
Figure 8: Implementing organizations, Swedish aid to Tanzania, 2013-2015 (\$ million)

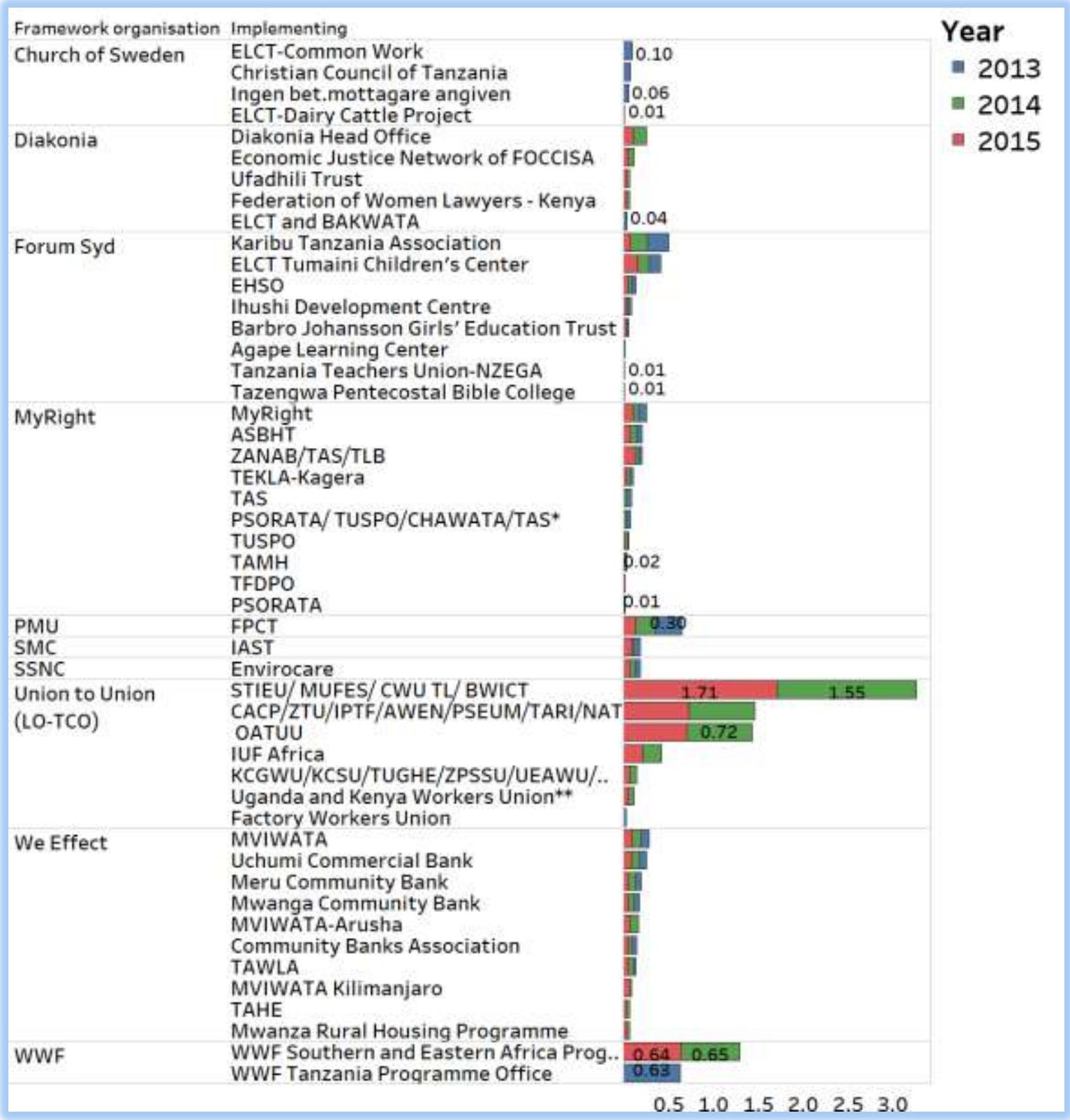

Source: SIDA CSO database.

Note: See Appendix B, Box 4, for key to acronyms.

\section{WHERE DID THE MONEY GO?}

According to the sector classifications used on Openaid.se and IATI, in 2013, 50 percent of net ODA ( $\$ 61$ million) went to the government of Tanzania for GBS and 16 percent ( $\$ 19$ million) was allocated to electricity transmission and distribution. In 2014, the top five sectors funded by Swedish ODA were economic and development policy planning (29 percent of net ODA), strengthening of civil society (14 percent), research and scientific institutions (12 percent), health education (8 percent), and financial policy (7 percent). In 2015, more than 60 percent of net ODA went to GBS and electricity transmission and distribution; Sweden and other donors agreed to resume GBS to Tanzania that year in light of anti-corruption reforms that the government undertook. ${ }^{75}$ For details on the sectoral allocation of Swedish aid during 20132015, see Appendix D. 
Once aid flows enter a recipient government's budget, the IATI traceability link is broken, because a government's use of development cooperation funds is outside the scope of IATI. As a consequence, although we can verify that a high percentage of Swedish net development cooperation arrived in Tanzania through GBS (more than 60 percent in 2013 and 2015), IATI provides no information on how and where the government spent that money.

It is theoretically possible to assess developing-country government spending through budget tracking and/or open procurement mechanisms, such as Open Contracting. ${ }^{76}$ Currently, however, this process has limitations:

- Most budgets do not contain details at the line level on where donor support is used, which donors are involved, and which donor activities the funds come from.

- An initial version of the Open Contracting Standard was released in November 2014 but is still in its infancy. As of mid-2016, 14 governments had agreed to implement the Open Contracting Data Standard, but Tanzania was not among them. ${ }^{77}$

\section{Agriculture and rural development}

The incidence of poverty in Tanzania is mainly in the rural areas, where the majority of poor people depend on agriculture for their livelihoods. In 2011, rural Tanzanians accounted for 69 percent of the national population, with a poverty rate of 33 percent. In contrast, 15 percent of urban dwellers lived in poverty. ${ }^{78}$ UNDP's 2014 Human Development Report shows that 80 percent of the total population depends on agricultural livelihoods, and investing in agricultural productivity would have the most immediate impacts on poverty reduction and livelihoods improvement in Tanzania. ${ }^{79}$ Accordingly, increased income in the value chains of food production is one of the primary goals of SIDA's strategy for 2013-2019 $9^{80}$ and is expected to increase employment and incomes for poor people, primarily women.

However, using Openaid.se data, we could find evidence only that a small share of Swedish ODA supported agriculture in Tanzania. In addition, the Tanzanian government budget for fiscal 2013/2014 called for an 18 percent reduction in spending on the agricultural sector compared with the preceding year. ${ }^{81}$ Nevertheless, the high level of Swedish ODA going to rural electricity distribution and transmission shows a substantial investment in improved rural infrastructure, which would contribute indirectly to the agricultural sector.

Low Swedish support to agriculture is not surprising, because agriculture is not a focal area in SIDA's global strategy, although SIDA does focus on inclusive economic development and sustainable natural resource management. In 2016, Sweden devoted only 2-3 percent of its worldwide aid spending to agriculture. ${ }^{82}$

In response to our inquiry about whether it will be possible to meet the agricultural development goals of the results strategy for SIDA in Tanzania, ${ }^{83}$ the Swedish Embassy stated, "Yes, it is the embassy's assessment that we will reach the intended results in agricultural markets by the end of the strategy period, that is, December 2019." ${ }^{84}$ Likewise, SIDA's 2015 report on the strategy (available only in Swedish at present) indicates progress on achieving the agricultural markets goal. The report notes that SIDA-funded projects implemented by AECF included "initiatives aimed at developing agricultural markets." Its projects "have contributed a total of 1,138 new jobs in agriculture and renewable energy." The report estimates that 49,950 households experienced increased income as a result of projects that SIDA supported. In addition, UNDP's "Economic Empowerment" project, which received Swedish funding, contributed in 2014/2015 "to productivity increases in the agricultural sector for small-scale farmers. More than 3,000 small-scale farmers have been trained in handling and storing harvested crops and thus increasing income.." ${ }^{85}$ At the same time, the report notes poor progress on SIDA's goal of 
supporting secure land tenure for small-scale farmers, an area of concern in terms of supporting rural poverty reduction.

\section{Gender equality}

In the IATI Standard, there is a "policy marker" field that identifies an activity's policy theme. In the case of gender equality, the standard permits publishers to report using the OECD DAC Creditor Reporting System's gender equality marker. ${ }^{86}$ This indicates that an activity "is intended to advance gender equality and women's empowerment or reduce discrimination and inequalities based on sex," either as a "principal objective" or a "significant objective." The DAC defines measures that advance women's empowerment as those that "reduce social, economic, or political power inequalities between women and men, girls and boys, ensure that women benefit equally with men from the activity, or compensate for past discrimination." ${ }^{87}$

Sweden reports its policy markers by activity on Openaid.se. At present, the policy markers are not searchable, so we manually reviewed all of the 2013-2015 activities to see whether they included the gender equality policy marker.

SIDA has explained that it marks activities as having gender equality as a principal objective when the contribution aims directly at advancing gender equality; that is, it would not have been implemented without the gender equality policy objective. Activities with gender equality as a significant objective aim partly at advancing gender equality; however, these would have been implemented even without the gender equality policy objective. Activities where gender equality is "not targeted" are those where the contribution is not relevant for the gender equality policy objective. $^{88}$

For 2013 , Sweden reported that of $\$ 123$ million in aid disbursed to Tanzania, 6.5 percent ( $\$ 8$ million) had gender equality as a principal objective, while fully 86 percent ( $\$ 106$ million) had it as a significant objective. Table 3 shows the sectoral allocation of the activities marked with gender equality as an objective. Forty-four percent ( $\$ 3.5$ million) of the funds allocated with gender equality as a principal objective went to medical services, and another 21 percent $(\$ 1.7$ million) went to decentralization and support to sub-national government. Health education, strengthening of civil society, human rights, and social mitigation of HIV/AIDS received most of the remainder.

Of the funds disbursed to projects with a significant gender equality objective, 58 percent $(\$ 61$ million) went to GBS. Sweden and other donors that participated in the Budget Support Development Partners' Group have noted that budget support financed girls' education and facilitated the creation of job opportunities for women, particularly in nursing ${ }^{89}$ An additional 18 percent of the funds disbursed with a significant gender equality objective ( $\$ 19$ million) went to electricity transmission and distribution.

As Figure 9 shows, the bulk of the resources with a gender equality policy marker arrived in Tanzania for implementation by Tanzanian entities (government or NGO). In 2013, we found that 88 percent ( $\$ 7$ million) of the aid marked as having gender equality as a principal objective went to Tanzania-based NGOs. ${ }^{90}$ The remainder went to international NGOs and Swedenbased NGOs. Of the amount disbursed to projects with a significant gender equality objective, 71 percent ( $\$ 75$ million) arrived in Tanzania and went to the government.

In 2014, about 39 percent of Swedish aid disbursed to Tanzania (\$21 million) had a principal gender equality objective. This represented a 32-percentage-point increase over the previous year (see Figure 10). We note that Sweden launched its feminist foreign policy in October 2014, with the aim of contributing to gender equality and the full enjoyment of human rights by all women and girls. ${ }^{91}$ We cannot say for certain, however, whether this new policy was a driver in the increase in aid marked with a principal gender equality objective. 
More than 75 percent of the funds for projects marked with a principal gender equality objective (\$16 million) was disbursed to UNDP for economic and development policy planning. Just 5 percent (\$1.1 million) arrived in Tanzania via Tanzania-based NGOs (see Table 3 and Figure 9).

Table 3: Implementing organization of activities with gender equality policy markers by sector (\$ million)

\begin{tabular}{|c|c|c|c|c|c|}
\hline \multirow[t]{2}{*}{ Category } & \multirow[t]{2}{*}{ Implementing organization } & \multirow[t]{2}{*}{ Sector } & \multicolumn{3}{|c|}{ Transaction year } \\
\hline & & & 2013 & 2014 & 2015 \\
\hline \multirow{14}{*}{$\begin{array}{l}\text { Principal } \\
\text { objective }\end{array}$} & UNDP & Economic and development policy/planning & & 15.7 & 8.0 \\
\hline & \multirow[t]{7}{*}{ Tanzania-based NGOs } & $\begin{array}{l}\text { Decentralization and support to sub-national } \\
\text { government }\end{array}$ & 1.7 & & \\
\hline & & Financial policy and administrative management & & & 1.4 \\
\hline & & Human rights & 0.3 & 0.1 & \\
\hline & & Medical services & 3.5 & & \\
\hline & & Social mitigation of HIV/AIDS & 0.6 & & \\
\hline & & STD control including HIV/AIDS & 0.1 & & \\
\hline & & Strengthening of civil society & 0.7 & 1.0 & 0.8 \\
\hline & \multirow{2}{*}{ Sweden-based NGOs } & Health education & 0.8 & 2.7 & \\
\hline & & Strengthening of civil society & 0.1 & 0.7 & 0.5 \\
\hline & \multirow[t]{2}{*}{ Not specified } & Strengthening of civil society & & 0.2 & 0.3 \\
\hline & & Women's equality organizations and institutions & & 0.6 & 0.5 \\
\hline & International NGO & Sectors not specified & 0.3 & & \\
\hline & $\begin{array}{l}\text { Swedish University of } \\
\text { Agricultural Science }\end{array}$ & Agricultural research & & 0.1 & 0.1 \\
\hline \multicolumn{2}{|c|}{ Principal objective total } & & 8 & 21 & 12 \\
\hline \multirow[t]{19}{*}{$\begin{array}{l}\text { Significant } \\
\text { objective }\end{array}$} & \multirow[b]{8}{*}{ Recipient government } & $\begin{array}{l}\text { Decentralization and support to sub-national } \\
\text { government }\end{array}$ & 0.2 & 0.1 & 0.1 \\
\hline & & Education facilities and training & 0.3 & 2.3 & \\
\hline & & Education policy and administrative management & & & 1.4 \\
\hline & & Electricity transmission and distribution & 11.8 & & 31.8 \\
\hline & & Energy policy and administrative management & 0.8 & 2.3 & 0.6 \\
\hline & & General budget support & 61.4 & & 32.6 \\
\hline & & Public finance management & & 0.6 & 0.4 \\
\hline & & Sectors not specified & 0.5 & & \\
\hline & \multirow{4}{*}{ Not specified } & Agricultural services & 0.4 & 0.3 & 0.2 \\
\hline & & Business support services and institutions & 1.9 & & \\
\hline & & Education policy and administrative management & & & 0.2 \\
\hline & & Elections & & & 0.04 \\
\hline & & Electricity transmission and distribution & 7.3 & 0.1 & 0.01 \\
\hline & & Energy policy and administrative management & & & 0.7 \\
\hline & & Media and free flow of information & 2.5 & 0.4 & 1.4 \\
\hline & & Research/scientific institutions & & & 2.3 \\
\hline & & $\begin{array}{l}\text { Sectors not specified } \\
\text { Trade facilitation }\end{array}$ & 1.5 & & $\begin{array}{l}0.3 \\
1.2\end{array}$ \\
\hline & $\begin{array}{l}\text { University, college, or other } \\
\text { teaching institution, research } \\
\text { institute, or think tank }\end{array}$ & Research/scientific institutions & 4.0 & 5.8 & 4.2 \\
\hline & International NGO & Health education & 2.5 & 1.3 & \\
\hline
\end{tabular}




\begin{tabular}{|c|c|c|c|c|c|}
\hline \multirow[t]{24}{*}{ Category } & \multirow[t]{5}{*}{ Implementing organization } & \multirow[t]{2}{*}{ Sector } & \multicolumn{3}{|c|}{ Transaction year } \\
\hline & & & 2013 & \multirow[t]{2}{*}{2014} & \multirow[t]{2}{*}{2015} \\
\hline & & Human rights & 3.8 & & \\
\hline & & Material relief assistance and services & & & 1.1 \\
\hline & & Strengthening civil society & 0.8 & 1.3 & 0.3 \\
\hline & \multirow[t]{5}{*}{ Tanzania-based NGO } & Agricultural development & & & 0.9 \\
\hline & & Education policy and administrative management & & & 0.4 \\
\hline & & Financial policy and administrative management & & 3.5 & \\
\hline & & Human rights & 0.8 & 0.3 & 0.2 \\
\hline & & Legal and judicial development & 1.4 & 1.9 & 1.2 \\
\hline & \multirow[t]{8}{*}{ Sweden-based NGO } & Biodiversity & & & 0.9 \\
\hline & & $\begin{array}{l}\text { Environmental policy and administrative } \\
\text { management }\end{array}$ & 0.2 & 1.3 & 0.1 \\
\hline & & Informal/semi-formal financial intermediaries & & 0.1 & \\
\hline & & Low-cost housing & & 0.1 & \\
\hline & & Multi-sector education/training & & 0.2 & 0.1 \\
\hline & & Promotion of development awareness & & 0.1 & \\
\hline & & Rural development & & 0.5 & 0.2 \\
\hline & & Strengthening of civil society & 1.7 & 2.7 & 1.1 \\
\hline & \multirow[t]{2}{*}{ Save the Children } & Human rights & 0.4 & 0.6 & 0.9 \\
\hline & & Strengthening of civil society & & 0.9 & 0.8 \\
\hline & World Bank Group (WB) & Energy policy and administrative management & 2.0 & 0.4 & \\
\hline & \multirow[b]{2}{*}{ The Swedish Institute } & Business support services and institutions & & & 0.1 \\
\hline & & Higher education & & & 1.0 \\
\hline & $\begin{array}{l}\text { International Federation } \\
\text { of Red Cross and Red } \\
\text { Crescent Societies }\end{array}$ & Material relief assistance and services & & & 0.6 \\
\hline \multicolumn{2}{|c|}{ Significant objective total } & & 106 & 27 & 88 \\
\hline
\end{tabular}

Source: Openaid.se.

Note: A blank cell in the table indicates no data reported for the year in question.

Another 51 percent of Swedish aid to Tanzania in 2014 (\$27 million) was disbursed to projects with a significant gender objective, of which more than 40 percent went to research institutions and strengthening of civil society. About 41 percent of the aid marked with this objective arrived in Tanzania through the national government ( $\$ 5$ million) and Tanzania-based NGOs ( $\$ 6$ million).

In 2015, the percentage of total ODA disbursed to projects with a principal objective of gender equality fell significantly while the funds going to projects with a significant gender equality objective rose (see Figure 10). Only 11 percent ( $\$ 12$ million) was allocated to projects with a principal gender equality objective; this was still a higher share than in 2013. As in 2014, more than 75 percent of these funds were allocated to economic and development policy planning. Moreover, 86 percent of disbursed ODA ( $\$ 88$ million) went to projects with a significant gender objective. As in 2013, GBS and electricity transmission and distribution were the main sectors receiving funds marked with this objective. 
Examining the descriptions of some of the Swedish aid projects in Tanzania that carried gender equality policy markers, we found that some targeted the needs and well-being of women and girls. For example, Uppsala University implemented a research project that looked at how nutritional supplements in early childhood lead to improved female educational attainment.

Other project descriptions more clearly emphasized women's empowerment, as defined by the DAC. Examples include the following:

- Support for the Tanzania Gender Networking Programme (TGNP), a Tanzanian NGO that seeks to help build a vibrant, transformative feminist movement in Tanzania that is capable of challenging patriarchy and neoliberalism at all levels. According to Sweden's 2013 IATI data, the project contributed to progress in grassroots organizing, increased agriculture and social services budget allocations benefiting women and other marginalized groups, and specification of these groups' constitutional rights.

- Support for a project of the Tanzania Women Lawyers Association (TAWLA) that promotes respect for the rights of women and children. According to Sweden's 2014 IATI data, this project also contributed to advancing the constitutional rights of women and children. In addition, TAWLA "worked with community radios to raise awareness on good governance, accountability, gender equity and sexual reproductive health and rights. TAWLA also introduced a toll-free telephone line to expand access to legal aid services." ${ }^{92}$

- Support for Femina Strategy, which runs from 2013 to 2018 and targets young people ages 13-30 through its media platform. It envisions a gender-equal society in which youth are confident and competent change makers.

- Funding for a research project at Linkoping University focusing on how women entrepreneurs in Kenya, Tanzania, and Uganda resolve conflicts in the face of limited access to formal commercial justice mechanisms. 
Figure 9: Implementing organizations for activities with a gender equality policy marker, 2013-2015 (\$ million) ${ }^{93}$

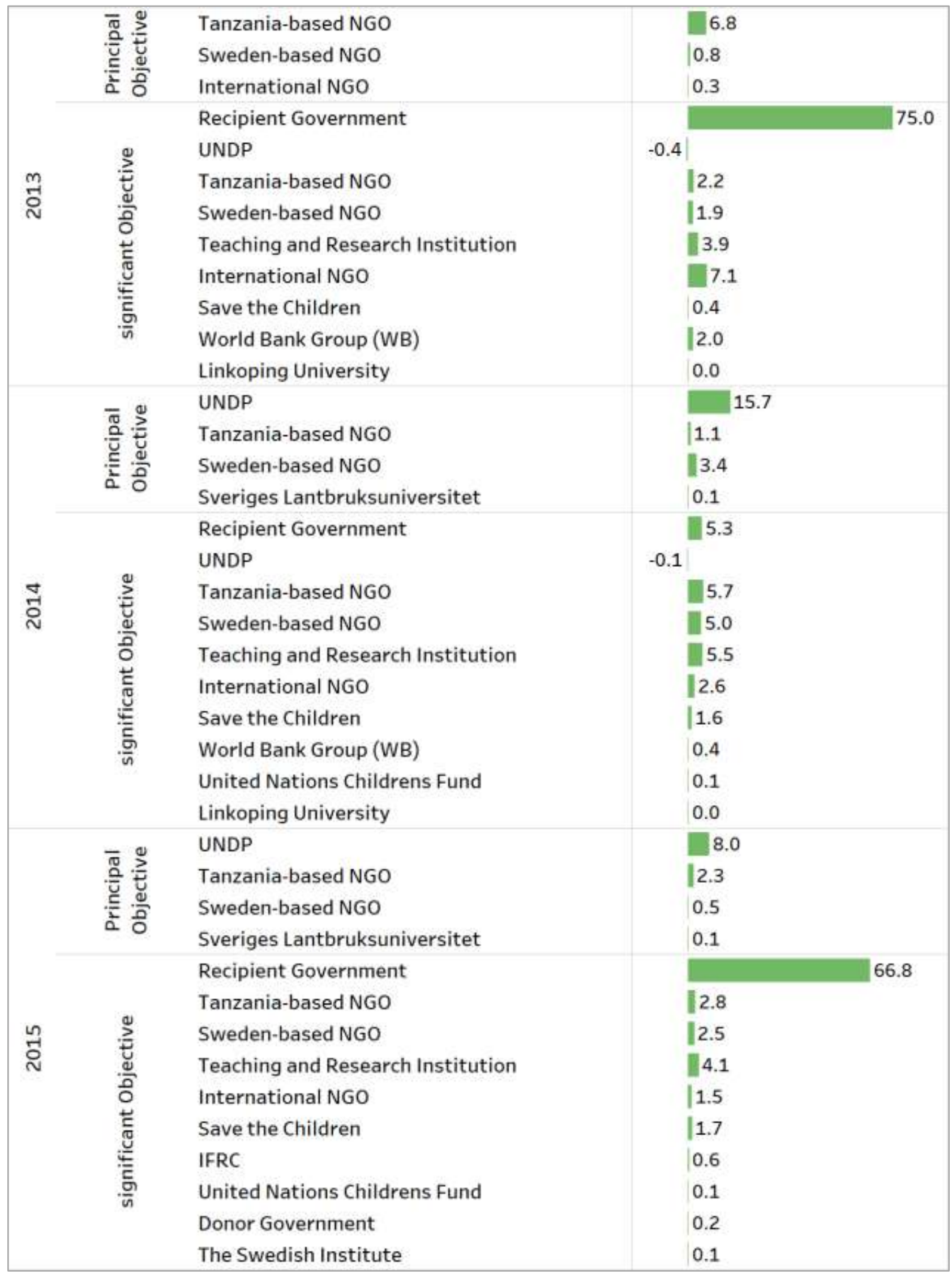

Source: Openaid.se 
Figure 10: Share of Swedish aid disbursements to Tanzania with gender policy markers (\%), 2013-2015

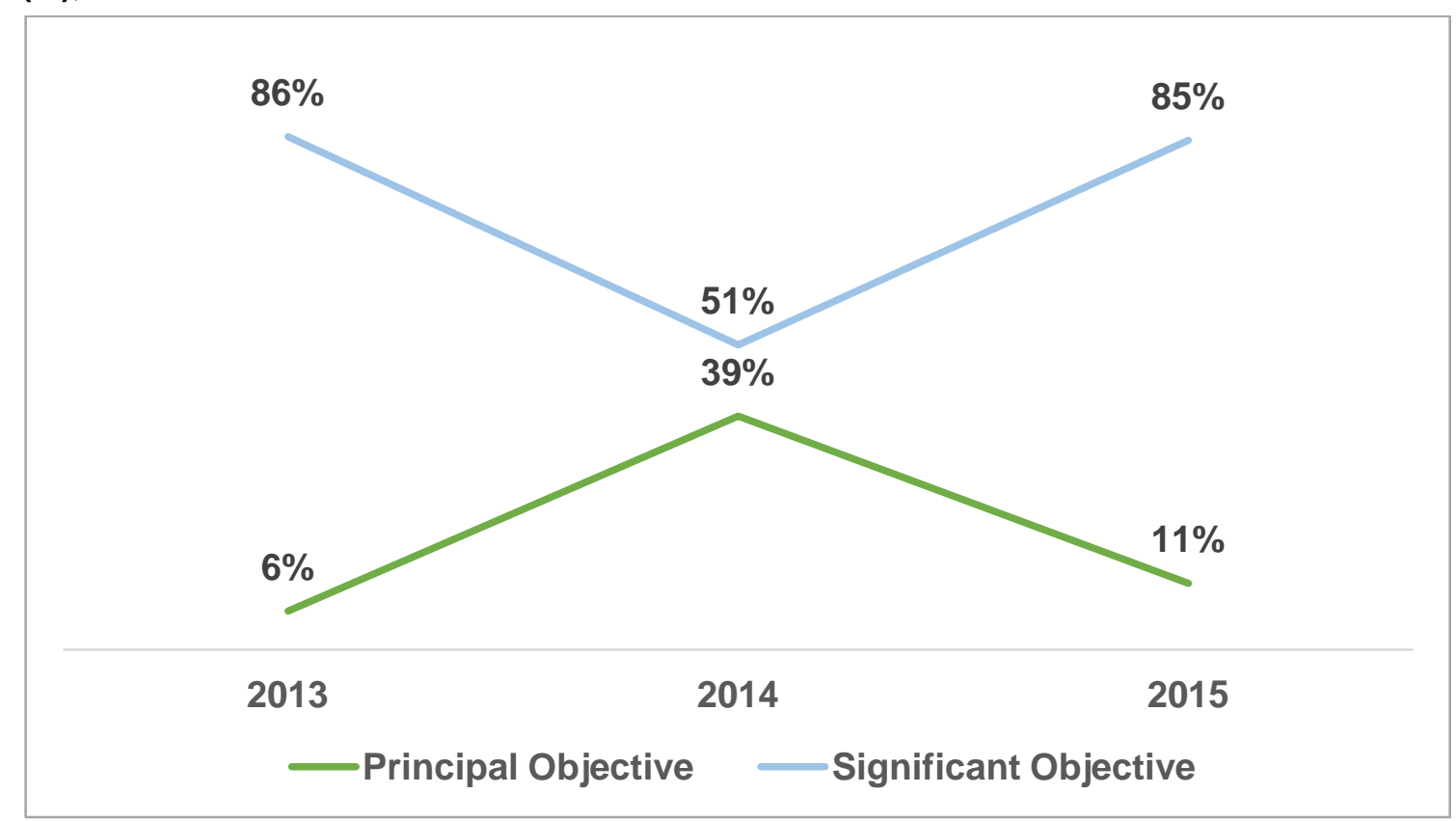

Source: Authors' analysis of Openaid.se data. 


\section{GAP ANALYSIS}

\section{LIMITATIONS OF OPENAID.SE}

Many recipients of Swedish ODA allocated to Tanzania do not publish data to IATI, and this severely reduces the traceability of the funds down the implementation chain. Had the recipients published their data to IATI, it would have enabled traceability to the final expenditures on goods and services.

The Openaid.se data for 2013-2015 also lack a "recipient region" field. This makes it impossible to assess the distribution of Swedish development cooperation transferred to Tanzania by subnational location, in order to determine, for example, whether there are any geographical biases or imbalances. A SIDA official told us, however, that a high percentage of Swedish development cooperation is program aid-e.g., GBS—rather than project-oriented, so geographical information is not especially relevant. ${ }^{94}$

Other limitations include the following:

- Lack of the implementing organization's name in the data. Openaid.se data has mixed the "implementing organization" with "implementing organization type," which is not particularly useful in determining the amount of money that reached the country.

- Absence of the implementing organization type/reference. A total of 38 out of 410 transactions (9 percent) are missing the implementing organization's information in the 2013-2015 Openaid.se data. Consistent naming of the implementing organizations would have allowed us to easily classify them as Tanzania-based or international organizations with country offices in Tanzania. All of this is important information for tracing net ODA to its end use.

- Inadequate activity titles and project descriptions.

- Inconsistency in the organization type that accompanies the title of the project. For example, the database codes AMREF Tanzania as an "international NGO" in 2013 and 2014 and as a "developing country-based NGO" in 2015. In fact, AMREF is an international NGO headquartered in Nairobi, Kenya, with an office in Tanzania.

- Project titles and descriptions that are the same in all three years. This makes it difficult to identify the name of the implementing organization based on the specific project it is going to implement using those particular funds. For example, one project is entitled "Development Programme Fund" and its description is exactly the same. In most cases, the descriptions of the projects include to whom and/or for what purpose Sweden provided the funds, among other information. So inadequate or missing project descriptions make it impossible to identify the implementing organization. SIDA acknowledges that improved project titles and descriptions would open up the black box of a large-scale, multi-project fund such as the Development Programme Fund. However, this would require some changes in standard operating procedures at the agency. ${ }^{95}$

- Project titles and short descriptions may indicate more than one type of activity. For example, the TAWLA implemented a project called "Enhancing Good Governance, Accountability and Gender Equity," ${ }^{96}$ and without a more detailed project description, it is difficult to tell to what extent the actual activities involve governance, women's rights, and both together. These limitations constrain our ability even to manually code the implementing organization to address the research questions. 
SIDA informed us that beginning in 2016, it made efforts to improve the quality of information about implementing organizations. These efforts include providing consistent and accurate information on organization type. ${ }^{97}$

\section{LIMITATIONS OF THE IATI STANDARD}

The IATI data do not indicate how much of the outgoing funds from a particular donor to attribute to the implementing agency's end-use expenditures in the designated recipient country. For example, if Restless Development received \$2 million from SIDA and \$4 million from USAID for a particular project in Tanzania, and spent $\$ 5$ million on local goods and services in that country, IATI offers no information on how much of SIDA's funding went to those expenditures. 


\section{ALIGNMENT BETWEEN SWEDISH AID AND THE TANZANIAN BUDGET}

\section{SWEDISH AID AND TANZANIAN BUDGET CLASSIFICATIONS}

We analyzed the Openaid.se data against the Tanzanian government's budget classifications to determine the amount of Swedish ODA that aligns with those classifications. We calculated the percentage of ODA allocated to each sector after deducting GBS from total ODA in 2013 and 2015 (see Appendix E). ${ }^{98}$ Because GBS is unearmarked money that supports a country's development planning and implementation through the national government budget, by definition it aligns completely with that budget. ${ }^{99}$ Tanzania has been the world's largest recipient of budget support funds in recent years, and during 2005-2012, it received $\$ 5$ billion in such support from all donors. ${ }^{100}$

Using the Openaid.se data sector classifications, we found the following:

- In 2013, 68 percent of Swedish ODA aligned with Tanzanian budget classifications, covering 20 out of 35 sectors that received Swedish aid.

- In 2014, the figure was 41 percent, accounting for 22 out of 38 sectors.

- In 2015, the pattern is similar to 2013: 68 percent of ODA and 25 out of 45 sectors aligned.

We note that information on how aid aligns with recipient-country budget classifications is a work in progress in the IATI Standard. In April 2018, IATI committed to publishing guidance on how to implement aid and budget alignment. Such information can play a crucial role in the budget process in developing countries; according to IATI's data use strategy, "The strongest demand and existing use case for IATI data is to inform budget preparation by finance ministries." 101

\section{"ON BUDGET" AID AND USE OF TANZANIAN SYSTEMS}

The available IATI data did not allow us to address our research question on the amount of Swedish development cooperation that is "on budget"-reported in Tanzanian budget documentation-and disbursed using Tanzanian systems. This is because the Tanzanian government does not publish data to IATI-few aid-recipient governments do so. 


\section{CONCLUSIONS AND RECOMMENDATIONS}

\section{CONCLUSIONS}

Our analysis shows that it is possible to determine net Swedish ODA allocated to Tanzania during 2013-2015 and the amount of nontransferable aid using IATI/Openaid.se data without any manual coding. We found it difficult, however, to determine the end use of net Swedish development cooperation to purchase goods and services in Tanzania using only IATI/Openaid.se data. This is because information on implementing organizations was lacking for some of the transactions.

When we manually coded the implementing organization based on project title and description we found the following:

- In 2013, 77 percent (\$95 million) of net Swedish ODA reached Tanzania directly. Of this amount, 79 percent went to the government of Tanzania, mostly as GBS.

- In 2014, 28 percent (\$15 million) of net Swedish ODA reached the country directly through Tanzania-based organizations. Of the $\$ 15$ million, 36 percent went directly to the government of Tanzania.

- In 2015, 80 percent of net ODA (\$82 million) definitely arrived in Tanzania through the government of Tanzania (66 percent) and Tanzania-based NGOs (14 percent).

- Though there is a high possibility that the remaining flows also reached Tanzania, at least in part, especially for those organizations that have offices in the country, we cannot verify that the money actually reached Tanzania, owing to incomplete data published to IATI/Openaid.se and incomplete or nonexistent IATI reporting on the part of the receiving organizations.

- Because some of the recipients of Swedish ODA did not publish their data to IATI, it was not possible to go beyond the first step of the implementation chain.

\section{Gender equality and women's empowerment}

Consistent with Sweden's declared feminist foreign policy, we found that the Swedish government tagged more than 90 percent of its aid disbursed to Tanzania during 2013-2015 with gender equality policy markers on Openaid.se. In addition, we found that the tagged funds went to a mix of activities. According to project descriptions on Openaid.se, some of the marked projects provided services targeted to meet the needs of women and girls. Other projects took a more gender transformative approach, promoting women's rights and empowerment.

In 2013 and 2015, a substantial portion of the aid reported with gender equality policy markers went to the government for general budget support (GBS). Sweden and other donors that provided GBS in those years consider it to have supported women's and girl's education and the creation of job opportunities for women.

In all three of the years under study, most of the funds with gender equality policy markers went to projects with a "significant" gender equality objective, rather than a "principal" objective. By the Swedish government's definition, these projects would have been implemented even without the gender equality policy objective. 


\section{Alignment between Swedish aid and the Tanzanian budget}

The analysis of Sweden's IATI/Openaid.se data to determine the amount of Swedish ODA (excluding ODA for GBS) that aligns with Tanzanian budget classification shows that

- 68 percent of total ODA aligned with Tanzanian budget classifications in 2013;

- 41 percent of ODA aligned with Tanzanian budget classifications in 2014; and

- 68 percent of ODA again aligned with Tanzanian budget classifications in 2015.

We could not determine whether Swedish development cooperation is on budget or disbursed using Tanzanian systems through analysis of either the available IATI data or Tanzanian government budget data.

\section{Gaps in Swedish IATI/Openaid.se data}

- The distribution of Swedish development cooperation transferred to Tanzania by subnational location cannot be determined from IATI data since Sweden does not report on the "recipient region" field. In some cases, project descriptions provide this information, as with the electricity project in southern Tanzania, but it is not provided consistently.

- Many recipient organizations fail to publish data to IATI. The Swedish government encourages implementers to publish but does not currently require them to do so, and it has no plans to make IATI reporting mandatory. ${ }^{102}$

- Information on implementing organizations is lacking.

- The quality of project titles and descriptions could improve.

- There is no identifier or marker that allows traceability of individual flows within activities.

- "Transaction type codes" are inconsistent across reporting organizations.

- When a project involves more than one country or activity, budget classification is lacking.

\section{RECOMMENDATIONS}

The government of Sweden should

- continue to encourage and support the recipients of its funds to publish their data to IATI, to enable further traceability;

- report the recipient region to IATI;

- make it possible to search which and how many activities include a particular policy marker, such as gender equality;

- increase the consistency of its ODA reports across IATI/Openaid.se and OECD/DAC; ${ }^{103}$

- publish the name of implementing organizations for all ODA activities that it supports;

- report the implementing organization and the implementing organization type separately;

- maintain consistency in reporting the implementing organization type;

- provide details on country budgets when projects involve more than one country; ${ }^{104}$ and

- improve the titles and descriptions of projects.

Implementing agencies should make some changes in how they report to IATI:

- The World Bank and UNDP should include details on incoming funds, including the source, in their IATI reports.

- Twaweza should report details on incoming funds to IATI and ensure that data are complete and accurate. 
- Restless Development should revise its data and ensure that transaction flow type data are accurate.

- All recipients of Swedish ODA should report their data to IATI.

IATI should

- work on methods that would allow traceability of individual flows within activities; ${ }^{105}$

- encourage reporting organizations to use the IATI code list and report according to the IATI Standard;

- continue to work with the Joined-up Data Alliance (JDA), which brings together open publishing standards in diverse fields, such as development cooperation and public contracting, "to collaborate on the development and usage of data standards." ${ }^{106}$ This would potentially allow traceability across aid flows and government budgets in aid-receiving countries;

- promote best practices to publishers with regard to aligning aid and recipient-country budget classifications; and

- encourage consistency across publishing organizations in reporting "transaction type."107 


\section{APPENDICES}

\section{APPENDIX A: AID TYPE AND ITS DESCRIPTION}

\begin{tabular}{|c|c|c|}
\hline Aid type code & Name & Description \\
\hline$A 01$ & General budget support & $\begin{array}{l}\text { These unearmarked contributions to the government } \\
\text { budget include funding to support the implementation of } \\
\text { macroeconomic reforms (structural adjustment } \\
\text { programs, poverty reduction strategies). } \\
\text { Budget support is a method of financing a recipient } \\
\text { country's budget through a transfer of resources from an } \\
\text { external financing agency to the recipient government's } \\
\text { national treasury. }\end{array}$ \\
\hline$B 01$ & $\begin{array}{l}\text { Core support to NGOs, } \\
\text { other private bodies, } \\
\text { public-private } \\
\text { partnerships (PPPs), } \\
\text { and research institutes }\end{array}$ & $\begin{array}{l}\text { Funds are paid to NGOs (local, national, regional, and } \\
\text { international) for use at the latter's discretion and } \\
\text { contribute to programs and activities that NGOs have } \\
\text { developed themselves and that they implement on their } \\
\text { own authority and responsibility. Core contributions to } \\
\text { PPPs, funds paid to foundations (e.g., philanthropic } \\
\text { foundations), and contributions to research institutes } \\
\text { (public and private) are also recorded here. }\end{array}$ \\
\hline B02 & $\begin{array}{l}\text { Core contributions to } \\
\text { multilateral institutions }\end{array}$ & $\begin{array}{l}\text { These funds are classified as multilateral ODA (all other } \\
\text { categories fall under bilateral ODA). The recipient } \\
\text { multilateral institution pools contributions so that the } \\
\text { individual contributions lose their identity and become an } \\
\text { integral part of the institution's financial assets. }\end{array}$ \\
\hline$B 03$ & $\begin{array}{l}\text { Contributions to specific- } \\
\text { purpose programs and } \\
\text { funds managed by } \\
\text { international } \\
\text { organizations } \\
\text { (intergovernmental and } \\
\text { NGO) }\end{array}$ & $\begin{array}{l}\text { In addition to their core-funded operations, international } \\
\text { organizations set up and raise funds for specific } \\
\text { programs and fund facilities with a clearly identified } \\
\text { sectoral, thematic, or geographical focus. Donors' } \\
\text { bilateral contributions to such programs and funds are } \\
\text { recorded here-e.g., "UNICEF girls' education," } \\
\text { "Education For All Fast Track Initiative," and various trust } \\
\text { funds, including for reconstruction (e.g., the Afghanistan } \\
\text { Reconstruction Trust Fund). }\end{array}$ \\
\hline B04 & $\begin{array}{l}\text { Basket funds/pooled } \\
\text { funding }\end{array}$ & $\begin{array}{l}\text { The donor contributes funds to an autonomous account, } \\
\text { managed jointly with other donors and/or the recipient. } \\
\text { The account has specific purposes, modes of } \\
\text { disbursement, accountability mechanisms, and a limited } \\
\text { time frame. Basket funds are characterized by common } \\
\text { project documents, common funding contracts, and } \\
\text { common reporting/audit procedures with all donors. }\end{array}$ \\
\hline C01 & $\begin{array}{l}\text { Project-type } \\
\text { interventions }\end{array}$ & $\begin{array}{l}\text { A project is a set of inputs, activities, and outputs, } \\
\text { agreed-upon with the partner country, to reach specific } \\
\text { objectives and outcomes within a defined time frame, } \\
\text { with a defined budget and a defined geographical area. }\end{array}$ \\
\hline D01 & Donor country personnel & $\begin{array}{l}\text { This consists of experts, consultants, teachers, } \\
\text { academics, researchers, volunteers, and contributions to } \\
\text { public and private bodies for sending experts to } \\
\text { developing countries. }\end{array}$ \\
\hline D02 & $\begin{array}{l}\text { Other technical } \\
\text { assistance }\end{array}$ & $\begin{array}{l}\text { This provision of technical assistance in recipient } \\
\text { countries (excluding projects described in C01, technical } \\
\text { assistance performed by donor experts reported under } \\
\text { D01, and scholarships/training in donor country reported } \\
\text { under E01) includes training and research, language } \\
\text { training, South-South studies, research studies, } \\
\text { collaborative research between donor and recipient }\end{array}$ \\
\hline
\end{tabular}




\begin{tabular}{|l|l|l|}
\hline Aid type code & Name & $\begin{array}{l}\text { Description } \\
\text { universities and organizations, local scholarships, and } \\
\text { development-oriented social and cultural programs. This } \\
\text { category also covers ad hoc contributions such as } \\
\text { conferences, seminars and workshops, exchange visits, } \\
\text { and publications. }\end{array}$ \\
\hline E01 & $\begin{array}{l}\text { Scholarships and } \\
\text { training in donor country }\end{array}$ & $\begin{array}{l}\text { These are financial aid awards for individual students } \\
\text { and contributions to trainees. }\end{array}$ \\
\hline included elsewhere & $\begin{array}{l}\text { These are administrative costs of development } \\
\text { assistance programs not already included under other } \\
\text { ODA items as an integral part of the costs of delivering } \\
\text { or implementing the aid provided. This category covers } \\
\text { situation analyses and auditing activities. }\end{array}$ \\
\hline H01 & Development awareness & $\begin{array}{l}\text { This funding is for activities designed to increase public } \\
\text { support-i.e., awareness in the donor country of } \\
\text { development co-operation efforts, needs, and issues. }\end{array}$ \\
\hline
\end{tabular}

Source: Based on IATI code list.

\section{APPENDIX B: ORGANIZATIONS INVOLVED IN SWEDISH AID TO TANZANIA}

\section{Box 1: Extending organizations}

The Swedish International Development Cooperation Agency (SIDA) is Sweden's principal aid agency. It has the power to make decisions on about half of the Swedish aid budget. http://www.sida.se/English/About-us/Our-mission/?epieditmode=true

Swedfund is Sweden's development finance institution. http://www.swedfund.se/en/aboutswedfund/

The Swedish Institute (SI) is a public agency that promotes Sweden and Swedish issues by creating mutual relationships with other countries around the world. SI also helps Sweden reach international goals in areas such as foreign policy, education, international aid, and development. https://eng.si.se/about-si/

The Swedish National Audit Office (SNAO) is an independent auditing organization under the parliament. It contributes to the development of parliamentary control and the democracy of other countries through international assignments.

http://www.riksrevisionen.se/en/Start/About-us/

The Swedish Research Council (SRC) is a public agency under the authority of the Ministry of Education and Research. The SRC allocates funds for research, advises the government on research-related issues, and promotes gender perspectives in research, among other objectives.

https://www.vr.se/inenglish/aboutus.4.69f66a93108e85f68d48000123.html 


\section{Box 2: Tanzanian organizations}

Zanzibar Legal Services Centre (ZLSC) is a nongovernmental organization established to promote access to justice and advocacy for the respect and observance of human rights for poor, marginalized, and vulnerable people in Zanzibar. http://www.zlsc.or.tz/about.html

The Tanzania Gender Networking Programme (TGNP) is an activist nonprofit organization that emerged through a collective process of critical reflection by leaders of key women's and gender organizations to eliminate all forms of discrimination against women and other marginalized groups. https://tgnp.org/about/

Femina Hip is the largest multimedia platform for young Tanzanians, working with youth to promote healthy lifestyles and financial literacy.

http://www.kaributanzania.or.tz/index.php/2014-10-16-09-45-34/2014-10-16-10-30-

35/femina-hip

REPOA, a nongovernmental organization based in Tanzania, is a research institute that uses knowledge to facilitate socioeconomic development. Its research focuses mainly on growth and development, social protection, governance, and service delivery.

http://www.repoa.or.tz/

The Legal and Human Rights Centre (LHRC) is a private, autonomous, voluntary, nongovernmental, nonpartisan, and nonprofit sharing organization with a vision of a just and equitable society. By creating legal and human rights awareness, LHRC is dedicated to empowering the people of Tanzania to promote and safeguard human rights and good governance in the country. http://www.humanrights.or.tz/about-us/introduction-to-lhrc

The Association of Local Government Authorities of Tanzania (ALAT) is a national local government association that promotes and sustains the goals and principles of decentralization with a goal of fostering and promoting smooth local government development in Tanzania. http://www.migration4development.org/en/actorsnetworks/association-local-authorities-tanzania-alat

Comprehensive Community Based Rehabilitation Tanzania (CCBRT) is the largest local NGO that provides disability services in Tanzania. It aims to empower people with disabilities and their families, improve their quality of life, and ensure access to medical and rehabilitative treatment. http://www.ccbrt.or.tz/about-us/

The Union of Tanzania Press Clubs (UTPC), a nongovernmental organization, is an umbrella body of press clubs located throughout the country. UTPC's mission is to create an environment that enables strong, efficient, and effective press clubs, which contribute to a democratic and just society. http://www.utpc.or.tz/index.php/da/who-are-we

The Pastoralists Indigenous Non-Governmental Organizations Forum (PINGO's FORUM) is a coalition of indigenous peoples' organizations working in Tanzania for the rights of marginalized indigenous pastoralists and hunter-gatherer communities by lobbying and advocating for change on good governance and human rights.

http://www.pingosforum.or.tz/\#

The Rural Energy Agency (REA) is an autonomous body under the Ministry of Energy and Minerals of the United Republic of Tanzania that promotes and facilitates improved access to modern energy services in rural areas of mainland Tanzania. http://rea.go.tz/AboutUs/AboutREA/tabid/144/Default.aspx

The Media Council of Tanzania (MCT) is a non-statutory national media body that exists to enhance the media profession; support a code of ethics; and influence policies, legislation, and practices in Tanzania. MCT's mission is to create an environment that enables a strong and ethical media that contributes to a more democratic and just society. https://milunesco.unaoc.org/mil-organizations/media-council-of-tanzania-mct/ 


\section{Box 3: Sweden-based NGOs}

Forum Syd, Sweden's largest civil society platform, is an association of nongovernmental organizations that work to enable people to organize to claim their rights and take control of their lives. Forum Syd mediates grants from SIDA to Swedish organizations cooperating with local partners in 70 countries and has country offices in Belarus, Cambodia, Colombia, Kenya, and Somalia. http://www.forumsyd.org/int/

RFSU TZ Men equal partner: RFSU (Swedish Association for Sexuality Education), a nonprofit Swedish organization, is a leading organization in the field of sexual and reproductive health and rights. It has partnerships and projects in many developing countries, including Tanzania. Contrary to what Openaid.se indicates, RFSU says that its "work in Tanzania is not financed by SIDA." http://www.rfsu.se/en/Engelska/About-rfsu/

The LO-TCO Secretariat is supported by two Swedish labor union confederations and is dedicated to promoting a more equal distribution of power and resources to eradicate poverty in the world, to fostering equality and welfare, and to strengthening democracy by supporting the creation and development of independent, democratic trade unions throughout the world. https://www.devex.com/organizations/lo-tco-secretariat-ofinternational-trade-union-development-cooperation-46505

Swedish Society for Nature Conservation (SSNC) is a charitable environmental organization that works on climate change, seas and fishing, forests, agriculture, and environmental toxins both nationally and internationally.

http://www.naturskyddsforeningen.se/in-english/about-us

Diakonia is a faith-based Swedish development organization that does not implement projects on its own. It supports and works with local partner organizations in 30 countries to ensure that more people are able to live dignified lives. Headquartered in Sweden, it has regional offices in Bogota, Chiang Mai, Jerusalem, and Nairobi. It works in nine African countries, but Tanzania is not on the list. http://www.diakonia.se/en/Where-we-work/

PMU is one of Sweden's major aid NGOs, with a mission to lead and develop joint relief work and combat poverty in all its forms through long-term development projects and humanitarian actions with partners in 35 countries, including Tanzania.

https://translate.google.com/translate?hl=en\&sl=sv\&u=https://pmu.se/sydsudan/\&prev=sea rch

The Swedish Mission Council (SMC) is a forum for churches and Christian organizations that work to provide opportunities for people and societies to change. Between 2013 and 2015 SMC distributed 130 million SEK of SIDA funds annually to development work carried out by member organizations in collaboration with partner organizations in about 50 countries. http://www.missioncouncil.se/en/om-smr/

The Swedish Church (also known as the Church of Sweden) is the largest Christian denomination in Sweden. It is a member of the Lutheran World Federation. https://www.svenskakyrkan.se/english

MyRight, the Swedish disability rights movement's umbrella, is an aid organization that works to ensure that persons with disabilities are better able to access their rights by supporting projects and programs that help to make disability organizations stronger, more democratic, and better able to participate in social development. http://myright.se/english/about-myright/

We Effect, formerly the Swedish Cooperative Centre, is a development cooperation organization that takes a long-term, rights-based approach in the areas of rural development, housing, gender equality, and access to land in order to effect change. http://www.weeffect.org/about-us/ 


\section{Box 4: Implementing organizations and their acronyms}

ASBHT: Association for Spina Bifida and Hydrocefalus in Tanzania

AWEN: African Women Education Network

BAKWATA: National Muslim Council of Tanzania

BWICT: Building and Woodworkers Industrial Council of Thailand

CACP: Central Asia Consortium Programme

CHAWATA: Tanzania Association of the Disabled TAS - Tanzania

CWU TL: Construction Workers Union of Timor Leste

EHSO: Educational and Health Support Organization

ELCT: Evangelical Lutheran Church in Tanzania

FOCCISA: Fellowship of Christian Councils in Southern Africa

FPCT: Free Pentecostal Church of Tanzania

IAST: International Aid Services Tanzania

International Federation for Spina Bifida and Hydrocephalus

IPTF: All India Primary Teachers' Federation

IUF: International Union of Food

KCGWU: Kenya County Government Workers' Union

KCSU: Kenya Civil Servants' Union

Kenya Electrical Trades and Allied Workers' Union

Kenya Union of Domestic Hotels, Educational Institutions, Hospitals and Allied Workers

MUFES: Malaysia Union of Forestry Department Employees

MVIWATA: Mtandao wa Vikundi vya Wakulima wa Tanzania/National Network of Farmers Groups Tanzania

NAT: National Alliance of Teachers.

National Union of Educational Institutions

NUEIS: National Union of Educational Institutions Nurses

Nurses and Midwives Union

OATUU: Organization of African Trade Union Unity

PSEUM: Private Schools Employees Union of Malawi

PSORATA: Psoriasis Association of Tanzania

STIEU: Sabah Timber Industry Employees Union

TAHE: Tanzania Association of Home Economics

TAMH: Tanzania Association for Mentally Handicapped

TARI: Teachers' Association of the Republic of Indonesia

TAS: Tanzania Albino Society—Chama Cha MaalbinoTanzania

TFDPO: Tanzania Federation of Disabled People's Organizations

TLB: Tanzania League of the Blind 
TUGHE: Tanzania Union of Government and Health Employees

TUSPO: Tanzania Users and Survivors of Psychiatry Organisation

TAWLA: Tanzania Women Lawyers Association

UEAWU: Uganda Electricity and Allied Workers Union

Uganda Electricity and Allied Workers Union

Vietnam Forestry

WWF: World Wide Fund for Nature

ZANAB: Zanzibar National Association of the Blind

ZPSSU: Zanzibar Public Service Sector Union

ZTU: Zanzibar Teachers' Union

\section{APPENDIX C: SUMMARY OF SWEDISH-TANZANIA IATI DATA PROJECT STATUS/CONTINUITY}

The table below summarizes project status of Swedish ODA to Tanzania during 2013-2015.

Among the projects financed during 2013-2015, 120 activities (30 percent of all activities) with a value of $\$ 208$ million (75 percent of net ODA during 2013-2015) are still active.

- For the 2013 transaction year, 14 projects (12 percent of all activities in 2013) were still active in early 2017.

- For the 2014 transaction year, 27 projects (21 percent) were still active in early 2017.

- For the 2015 transaction year, 79 projects (49 percent) were still active in early 2017.

Appendix C Table: Summary of Swedish-Tanzania IATI data project status

\begin{tabular}{|c|c|c|c|c|c|c|c|c|}
\hline \multirow[b]{3}{*}{$\begin{array}{l}\text { Project end } \\
\text { date }\end{array}$} & \multicolumn{5}{|c|}{ Transaction date } & & \multicolumn{2}{|l|}{ Total } \\
\hline & \multicolumn{2}{|l|}{2013} & \multicolumn{2}{|l|}{2014} & \multicolumn{2}{|l|}{2015} & \multirow{2}{*}{$\begin{array}{l}\text { Transaction } \\
\text { value in } \\
\text { million }\end{array}$} & \multirow{2}{*}{$\begin{array}{l}\text { Number } \\
\text { of } \\
\text { activities }\end{array}$} \\
\hline & $\begin{array}{l}\text { Transaction } \\
\text { value in } \\
\text { million }\end{array}$ & $\begin{array}{l}\text { Number } \\
\text { of } \\
\text { activities }\end{array}$ & $\begin{array}{l}\text { Transaction } \\
\text { value in } \\
\text { million }\end{array}$ & $\begin{array}{l}\text { Number } \\
\text { of } \\
\text { activities }\end{array}$ & $\begin{array}{l}\text { Transaction } \\
\text { value in } \\
\text { million }\end{array}$ & $\begin{array}{l}\text { Number of } \\
\text { activities }\end{array}$ & & \\
\hline 6/28/2017 & $\$ 63.30$ & 5 & $\$ 18.39$ & 3 & $\$ 41.97$ & 7 & $\$ 123.66$ & 15 \\
\hline $12 / 28 / 2017$ & $\$ 3.74$ & 3 & $\$ 3.41$ & 4 & $\$ 2.35$ & 20 & $\$ 9.50$ & 27 \\
\hline $3 / 28 / 2018$ & & & $\$ 0.13$ & 1 & $\$ 1.29$ & 3 & $\$ 1.41$ & 4 \\
\hline 6/28/2018 & $\$ 0.31$ & 1 & $\$ 1.93$ & 5 & $\$ 1.77$ & 6 & $\$ 4.00$ & 12 \\
\hline 8/28/2018 & & & $\$ 1.05$ & 7 & $\$ 0.55$ & 8 & $\$ 1.60$ & 15 \\
\hline 9/28/2018 & $\$ 0.69$ & 1 & $\$ 1.02$ & 1 & $\$ 2.37$ & 3 & $\$ 4.08$ & 5 \\
\hline $10 / 28 / 2018$ & & & $\$ 0.66$ & 3 & $\$ 1.03$ & 12 & $\$ 1.69$ & 15 \\
\hline $12 / 28 / 2018$ & & & & & $\$ 0.56$ & 1 & $\$ 0.56$ & 1 \\
\hline
\end{tabular}




\begin{tabular}{|l|l|l|l|l|l|l|l|l|}
\hline $2 / 28 / 2019$ & & & & $\$ 0.21$ & 1 & $\$ 0.21$ & 1 \\
\hline $6 / 28 / 2019$ & $\$ 15.08$ & 3 & $\$ 1.98$ & 2 & $\$ 15.24$ & 3 & $\$ 32.30$ & 8 \\
\hline $12 / 28 / 2019$ & & & & & $\$ 0.59$ & 1 & $\$ 0.59$ & 1 \\
\hline $6 / 28 / 2020$ & $\$ 4.22$ & 1 & $\$ 0.02$ & 1 & $\$ 5.32$ & 11 & $\$ 9.56$ & 13 \\
\hline $12 / 28 / 2020$ & & & & & $\$ 1.42$ & 1 & $\$ 1.42$ & 1 \\
\hline $6 / 28 / 2021$ & & & & & $\$ 17.80$ & 2 & $\$ 17.80$ & 2 \\
\hline Grand total & $\$ 87.34$ & 14 & $\$ 28.58$ & 27 & $\$ 92.46$ & 79 & $\$ 208.38$ & 120 \\
\hline
\end{tabular}

Source: IATI data.

Note: A blank cell in the table indicates no data reported for the year in question.

\section{APPENDIX D: SECTORAL SHARES OF NET SWEDISH AID TO} TANZANIA, 2013-2015 (\%)

\begin{tabular}{|c|c|c|c|}
\hline Sector & 2013 & 2014 & 2015 \\
\hline General budget support & 49.97 & & 31.88 \\
\hline Electricity transmission/distribution & 15.50 & 0.21 & 31.08 \\
\hline Economic and development policy/planning & & 29.18 & 8.40 \\
\hline Research/scientific institutions & 3.83 & 12.35 & 6.80 \\
\hline Democratic participation and civil society & 2.64 & 14.11 & 3.70 \\
\hline Health education & 2.61 & 7.56 & 0.05 \\
\hline Energy policy and administrative management & 2.32 & 5.08 & 1.29 \\
\hline Unspecified & 4.27 & 2.42 & 1.37 \\
\hline Financial policy and administrative management & & 6.57 & 1.39 \\
\hline Business support services and institutions & 5.43 & 1.23 & 0.06 \\
\hline Legal and judicial development & 1.12 & 3.54 & 1.16 \\
\hline Sectors not specified & 2.18 & 1.79 & 0.80 \\
\hline Education facilities and training & 0.26 & 4.26 & \\
\hline Media and free flow of information & 2.07 & 0.76 & 1.34 \\
\hline Public finance management & 0.40 & 2.05 & 0.77 \\
\hline Environmental policy and administrative management & 0.19 & 2.50 & 0.14 \\
\hline Medical services & 2.81 & & \\
\hline Trade facilitation & 1.25 & & 1.16 \\
\hline Education policy and administrative management & & & 1.91 \\
\hline Material relief assistance and services & & & 1.86 \\
\hline Decentralization and support to sub-national government & 1.54 & 0.22 & 0.07 \\
\hline
\end{tabular}




\begin{tabular}{|c|c|c|c|}
\hline Sector & 2013 & 2014 & 2015 \\
\hline Energy research & 0.49 & 0.75 & 0.38 \\
\hline Women's equality organizations and institutions & & 1.09 & 0.46 \\
\hline Malaria control & 0.03 & 0.89 & 0.32 \\
\hline Rural development & 0.00 & 0.97 & 0.21 \\
\hline Agricultural services & 0.33 & 0.59 & 0.22 \\
\hline Agricultural development & & & 0.93 \\
\hline Biodiversity & & & 0.93 \\
\hline Power generation/renewable sources & & 0.24 & 0.66 \\
\hline Social mitigation of HIV/AIDS & 0.50 & 0.01 & 0.07 \\
\hline Multi-sector education/training & 0.00 & 0.32 & 0.08 \\
\hline Educational research & 0.03 & 0.22 & 0.03 \\
\hline Agricultural research & & 0.18 & 0.06 \\
\hline Multi-sector aid for basic social services & & 0.16 & 0.06 \\
\hline Low-cost housing & & 0.18 & 0.04 \\
\hline Reproductive health care & & & 0.16 \\
\hline Tuberculosis control & 0.03 & 0.07 & 0.06 \\
\hline Informal/semiformal financial intermediaries & & 0.12 & 0.03 \\
\hline Promotion of development awareness & & 0.13 & \\
\hline Medical research & 0.03 & 0.07 & 0.03 \\
\hline Sexually transmitted disease control including HIV/AIDS & 0.09 & 0.00 & 0.02 \\
\hline Forestry research & & 0.08 & 0.03 \\
\hline Basic health care & & 0.06 & \\
\hline Small and medium-sized enterprise (SME) development & 0.05 & & \\
\hline Civilian peace building, conflict prevention, and resolution & & 0.03 & 0.01 \\
\hline Culture and recreation & 0.03 & & 0.01 \\
\hline Water supply and sanitation-large systems & & & 0.00 \\
\hline \multicolumn{4}{|l|}{ Information and communication technology (ICT) } \\
\hline Higher education & & & \\
\hline
\end{tabular}

Source: IATI data.

Note: A blank cell in the table indicates no data reported for the year in question. "Sectors not specified" means that this term was used in the IATI data. "Unspecified" indicates that the sector field in IATI was left blank. 


\section{APPENDIX E: ALIGNMENT OF SWEDISH AID AND TANZANIAN BUDGET CLASSIFICATIONS ${ }^{108}$}

\begin{tabular}{|c|c|c|c|c|}
\hline \multirow{3}{*}{$\begin{array}{l}\text { Sector name, Tanzanian } \\
\text { budget classification } \\
\text { (fiscal 2014/2015) }\end{array}$} & \multirow{3}{*}{$\begin{array}{l}\text { Sector classifications, } \\
\text { Openaid.se }\end{array}$} & \multirow{2}{*}{\multicolumn{3}{|c|}{$\begin{array}{l}\text { Openaid.se match } \\
\% \text { Swedish aid } \\
\text { allocated to sector }\end{array}$}} \\
\hline & & & & \\
\hline & & 2013 & 2014 & 2015 \\
\hline \multirow{6}{*}{$\begin{array}{l}\text { Education } \\
\text { - } \text { Technical, vocational } \\
\text { education and training } \\
\text { - } \text { Basic education } \\
\text { - } \text { Primary education } \\
\text { - } \text { Secondary education } \\
\text { - } \text { Higher education } \\
\text { - } \text { Teacher education }\end{array}$} & Education facilities and training & 0.52 & 4.22 & \\
\hline & Multisector education/training & 0.01 & 0.32 & 0.12 \\
\hline & Education research & 0.06 & 0.22 & 0.04 \\
\hline & Higher education & 0.25 & 0.52 & 1.50 \\
\hline & Research/scientific institutions & 8.00 & 13.00 & 10.00 \\
\hline & $\begin{array}{l}\text { Education policy and } \\
\text { administrative management }\end{array}$ & & & 2.00 \\
\hline \multirow{9}{*}{$\begin{array}{l}\text { Health } \\
\text { - Maternal health programs } \\
\text { - } \text { Primary health care services } \\
\text { - Preventing and combating } \\
\text { HIV/AIDS } \\
\text { - Procurement and distribution } \\
\text { of medicine, equipment } \\
\text { - Construction of hospitals }\end{array}$} & Basic health care & & 0.06 & \\
\hline & Reproductive health care & & & 0.24 \\
\hline & Health education & 5.00 & 8.00 & 0.07 \\
\hline & Malaria control & 0.05 & 1.00 & 0.50 \\
\hline & Medical research & 0.06 & 0.10 & 0.04 \\
\hline & Medical services & 6.00 & & \\
\hline & Social mitigation of HIV/AIDS & 1.00 & 0.01 & 0.10 \\
\hline & STD control including HIV/AIDS & 0.17 & 0.002 & 0.03 \\
\hline & Tuberculosis control & 0.06 & 0.10 & 0.09 \\
\hline \multirow{3}{*}{$\begin{array}{l}\text { Agriculture } \\
\text { - Irrigation } \\
\text { - } \quad \text { Fertilizer subsidies } \\
\text { - } \text { Agricultural inputs }\end{array}$} & Agricultural services & 0.66 & 0.59 & 0.31 \\
\hline & Agricultural development & & & 1.34 \\
\hline & Agricultural research & & 0.18 & 0.10 \\
\hline $\begin{array}{l}\text { Water } \\
\text { - Water supply and sanitation }\end{array}$ & Water supply and sanitation & & & 0.001 \\
\hline \multirow{4}{*}{$\begin{array}{l}\text { Energy and minerals } \\
\text { - Power generation, } \\
\text { transmission, and supply } \\
\text { - Natural gas and petroleum } \\
\text { - Mining }\end{array}$} & $\begin{array}{l}\text { Electricity } \\
\text { transmission/distribution }\end{array}$ & 31.00 & 0.22 & 45.00 \\
\hline & $\begin{array}{l}\text { Energy policy and administrative } \\
\text { management }\end{array}$ & 4.00 & 5.00 & 2.00 \\
\hline & Energy research & 1.00 & 0.75 & 0.54 \\
\hline & Power generation/renewable & & 0.24 & 1.00 \\
\hline
\end{tabular}




\begin{tabular}{|c|c|c|c|c|}
\hline & sources & & & \\
\hline \multirow{5}{*}{$\begin{array}{l}\text { Employment creation } \\
\text { - Youth entrepreneurs, skills } \\
\text { training, vocational guidance } \\
\text { and counseling, capacity } \\
\text { building, business } \\
\text { development, and financial } \\
\text { services for business start- } \\
\text { ups }\end{array}$} & $\begin{array}{l}\text { Small and medium-sized } \\
\text { enterprise (SME) development }\end{array}$ & 0.10 & & \\
\hline & $\begin{array}{l}\text { Business support services and } \\
\text { institutions }\end{array}$ & 11.00 & 1.23 & 0.10 \\
\hline & $\begin{array}{l}\text { Financial policy and administrative } \\
\text { management }\end{array}$ & & 7.00 & 2.00 \\
\hline & $\begin{array}{l}\text { Informal/semiformal financial } \\
\text { intermediaries }\end{array}$ & & 0.12 & 0.04 \\
\hline & $\begin{array}{l}\text { Multisector aid for basic social } \\
\text { services }\end{array}$ & & 0.16 & 0.06 \\
\hline
\end{tabular}

Source: IATI and Tanzanian budget data.

\section{ACKNOWLEDGMENTS}

Marc J. Cohen is Senior Researcher, Aid Effectiveness at Oxfam America. Tigist Mekuria, an economist, was an Aid Data Transparency Intern at Oxfam America in 2017.

The authors wish to recognize the late Simon Parish, of Development Initiatives, who created the methodology used in this report.

The authors are grateful to Tariq Ahmad, Anna Coryndon, Samantha Custer, Melinda Cuzner, Carl Elmstam, Heidi Fritschel, Aria Grabowski, Emil Morten Hansen, and Eluka Kibona for their assistance. 


\section{NOTES}

1 See https://www.aidtransparency.net/.

2 https://openaid.se/aid/?fb_locale=en_US.

3 The disaggregated shares add up to more than the total of 77 percent because of rounding.

4 Rupert Simons and Emmanuel Saffa Abdulai, "Ebola and Information: Why Donors Must Publish What They Fund," Global Views-Aid Transparency, July 14, 2015, https://www.devex.com/news/ebola-andinformation-why-donors-must-publish-what-they-fund-86506.

5 IATI is a voluntary, multistakeholder group of donor and recipient-country governments that seeks to improve the transparency of aid and development and humanitarian resources in order to increase their effectiveness in alleviating poverty (http://www.trimpact.nl/IATI.html).

6 http://www.aidtransparency.net/about.

7 See http://modernizeaid.net/wp-content/uploads/2014/09/MFAN Transparency OnePager_8.5x11_091214a.pdf.

8 See https://www.aidtransparency.net/.

9 Michael O'Donnell, Publishing Results to IATI: Will It Improve Learning and Accountability? Discussion paper (London: Bond, 2016), https://www.bond.org.uk/sites/default/files/resourcedocuments/publishing-results-to-iati-0316.pdf.

10 See Simons and Abdulai, op. cit., for evidence from Sierra Leone.

11 Wibrod Ntawiha and Conrad Zellmann, Reaching the Potential of IATI Data (Bristol, UK: Development Initiatives, 2017), http://devinit.org/wp-content/uploads/2017/03/reaching-the-potential-of-IATI-data.pdf.

12 See Simons and Abudlai, op. cit., for evidence from Sierra Leone.

13 Measurement of net aid flows is a longstanding concern; see, for example, Houmi Kharas, "Trends and Issues in Development Aid," Wolfensohn Center for Development Working Paper No. 1 (Washington: Brookings Institution, 2007), 7. https://www.brookings.edu/wpcontent/uploads/2016/06/11_development_aid_kharas.pdf.

14 Additionally, a good deal of the aid is not captured by the DAC because DAC rules exclude certain types of aid from "official development assistance."

15 For evidence on the accountability-efficiency link, see Julian Srodecki, "Improving Efficiency and Effectiveness through Increased Accountability to Communities: A Case Study of World Vision Tsunami Response in Sri Lanka," Humanitarian Exchange Magazine 39 (July 2008), https://odihpn.org/magazine/improving-efficiency-and-effectiveness-through-increased-accountabilityto-communities-a-case-study-of-world-vision\%c2\%92s-tsunami-response-in-sri-lanka/.

16 Ali Clare, Stefaan Verhulst, and Andrew Young, Open Aid in Sweden: Enhanced Transparency and Accountability in Development Cooperation (New York: Open Data's Impact, NYU Governance Lab, 2016), pp. 12-13, http://odimpact.org/static/files/case-study-sweden.pdf.

17 See "A Transparency Guarantee in Swedish Development Assistance," April 2, 2015, posted at http://www.regeringen.se/informationsmaterial/2010/06/ud10.052/.

18 See https://www.iatiregistry.org/publisher/about/sida.

19 Clare et al., Open Aid in Sweden.

20 https://Openaid.se/questions-and-answers/?method.

$21 \mathrm{https}: / / O p e n a i d . s e / a b o u t /$.

22 See Clare et al., Open Aid in Sweden.

23 Publish What You Fund, 2016 Aid Transparency Index, http://www.publishwhatyoufund.org/theindex/index-archive/. See also PWYF, "Comparison Chart," http://www.publishwhatyoufund.org/theindex/comparison-chart/. Note that our report was finalized before the publication of PWYF's 2018 Index, so we do not discuss data from that update.

24 These comments, which PWYF posted on its website when it published the 2016 Index, are no longer accessible. Contact info@publishwhatyoufund.org for further information.

25 http://dashboard.iatistandard.org/summary_stats.html.

26 Clare et al., Open Aid in Sweden, pp. 12-13.

27 Simon Parish, Marc J. Cohen, and Tigist Mekuria, Tracing US Development Flows: A Study of the Traceability of US Aid to Ghana, Oxfam Research Report, January 2018. DOI: 10.21201/2017.1558 
https://policy-practice.oxfam.org.uk/publications/tracing-us-development-flows-a-study-of-thetraceability-of-us-aid-to-ghana-620404.

28 See http://undocs.org/A/RES/69/313.

29 See http://www.undatarevolution.org/report/.

30 Simon Parish, Marc J. Cohen, and Tigist Mekuria, Follow the Money: Using International Aid Transparency Initiative Data to Trace Development Aid Flows to Their End Use, Oxfam Methodology Note (Washington, DC: Oxfam, 2018), DOI: 10.21201/2017.1800 https://policypractice.oxfam.org.uk/publications/follow-the-money-using-international-aid-transparency-initiativedata-to-trace-620416.

31 Parish, Cohen, and Mekuria, Tracing US Development Flows. Op.cit.

32 An activity is the unit of reporting in IATI. Activities are usually projects but can be any unit of development cooperation as defined by the publisher, such as a program or a contract.

33 http://www.sida.se/English/where-we-work/Africa/Tanzania/Our-work-in-Tanzania/.

34 http://www.sida.se/globalassets/global/countries-and-regions/africa/tanzania/sweden-tanzaniacooperation.pdf.

35 See http://stats.oecd.org/.

36 See http://www2.compareyourcountry.org/aid-statistics?cr=282\&lg=en\&page=21. The World Bank's International Development Association, the United States, the United Kingdom, the African Development Fund, the Global Fund, and European Union institutions were the top six donors.

37 See https://Openaid.se/wp-content/files_mf/1397116422Results_strategy_Tanzania_20132019.pdf.

38 lbid.

39 https://Openaid.se/aid/2014/.

40 Except for Iraq in 2006 and 2007 and the Democratic Republic of Congo in 2011 and 2012, which received exceptionally high volumes of Swedish ODA over the respective two-year periods.

41 See the "result" field of Openaid.se data (2013) for an activity with IATI-identifier (SE-0-SE-65117009101-TZA-15112).

42 Email to Oxfam from Carl Elmstam, Transparency Manager, SIDA, July 3, 2017.

43 Mark Anderson, "UK and International Donors Suspend Tanzania Aid after Corruption Claims," The Guardian, October 13, 2014, https://www.theguardian.com/global-development/2014/oct/13/uk-andinternational-donors-suspend-tanzania-aid-after-corruption-claims. See also Erick Kabendera and Mark Anderson, "Tanzania Energy Scandal Ousts Senior Politicians," The Guardian, December 24, 2014 https://www.theguardian.com/global-development/2014/dec/24/tanzania-energy-scandal-ousts-seniorpoliticians.

44 We use the term "non-transferable aid" to refer to aid that is not designed to arrive in the country owing to its modality and delivery mechanism. It includes debt relief, donor administrative costs, imputed student costs, refugee costs in donor countries and interest subsidies. These are derived from the DAC's technical definition of "country programmable aid," which is the proportion of ODA over which recipient countries have, or could have, a significant say. See http://www.oecd.org/dac/aidarchitecture/countryprogrammableaidcpafrequentlyaskedquestions.htm. See also Parish, Cohen, and Mekuria, Tracing US Development Flows. Op. cit.

45 See http://www.cnn.com/2017/02/23/europe/sweden-trump-refugees-integration.

46 http://www.sida.se/English/press/current-topics-archive/2016/deductions-for-in-country-refugee-costslead-to-redistribution-of-swedish-foreign-aid/.

47 http://popstats.unhcr.org/en/overview\#_ga=2.98474524.2032055576.14986672441566817348.1498667244.

48 We used project titles and descriptions to determine if these organizations are based in Tanzania, and we verified by accessing their websites that they are established in accordance with Tanzanian law. Note that the total amount that went directly to Tanzania, $\$ 95$ million, or 77 percent is not equal to 67 percent +10.57 percent due to rounding.

49 They each received just one transaction: World Bank $(\$ 1,995,947)$, Save the Children Sweden $(\$ 350,058)$ and UNDP $(-\$ 397,680)$.

50 Openaid.se only specifies "Save the Children" as the implementing organization, and does not indicate whether this is Save the Children International or one of its national member agencies. However, the title of the project makes it clear that Save the Children Sweden (Rädda Barnen) is the implementer.

51 The World Bank published a transaction from the International Development Association only, the "soft loan window" of the World Bank Group. 
52 A total of $\$ 0.2$ million from the Programme Development Fund Fiscal Year 2013 went to unidentified international NGOs.

53 We ascertained this from project titles and descriptions. In the case of the remaining two transactions, there is no way to identify the specific implementing organization from the Openaid.se data.

54 HRNS is not among those specified under "international NGOs" but under unspecified. We found HRNS to be an international NGO through the description of the project.

55 See http://twaweza.org/uploads/files/Twaweza\%20Financial\%20Report\%2031122015.pdf.

56 Recipient countries name and code are not consistent.

57 According to Restless Development's IATI data, the agency published $\$ 0.5$ million incoming funds from SIDA while the Swedish government reported a \$2 million disbursement to Restless Development in 2013 and 2014.

58 Göteborgs universitet, Karolinska Institutet, Linköpings universitet, Lunds universitet, Stockholms universitet, Sveriges Lantbruksuniversitet and Uppsala universitet.

59 About 40 percent of the transactions that went to Sweden-based NGOs are repayments (negative value).

60 Categorized on Openaid.se as universities, colleges, other teaching institutions, research institutes and think-tanks. Most of these projects were intended to improve Tanzanian national research through the cooperation of Tanzanian and Swedish universities, and there is a high possibility that at least some of the funds arrived in Tanzania, though the implementing organizations for these projects could not be identified.

61 Categorized on Openaid.se either as "other" or "Programme Development Fund FY 2013" without further identifying the implementing agency.

62 Secretariat for Donor Coordination of General Budget Support in Tanzania. Donors engaged in budget support in addition to Sweden in in 2014-2015 included Canada, Denmark, Finland, Germany, Ireland, Japan, UK, African Development Bank, European Union, and World Bank. The group was chaired by the Embassy of Finland in Tanzania. See http://www.tzdpg.or.tz/fileadmin/documents/dpg_internal/dpg_working_groups_clusters/prbs/Budget_S upport_in_Tanzania_2014-2015.pdf.

63 World Bank, UNDP, and Save the Children.

64 Restless Development, AMREF, and HRNS.

65 BEST-Advocacy, HakiElimu, Legal and Human Rights Centre, Agricultural Markets Development Trust (AMDT), Financial Sector Deepening Trust, FEMINA, Zanzibar Legal Services Centre (ZLSC).

66 International Federation of Red Cross and Red Crescent Societies, Save the Children, UNDP, Restless Development, Oxfam Great Britain, and Plan Sweden Humanitarian.

67 As in previous years, UNDP published data to IATI, but did not include the transactions from Sweden.

68 See http://cso.sida.se/.

$69 \mathrm{http}: / /$ www.globenet.org/preceup/pages/fr/chapitre/etatlieu/acteurs/f/m.htm.

70 SIDA's funding to international organizations is not included in the CSO database.

71 For Diakonia, none of the implementing organizations are based in Tanzania except ELCT and BAKWATA.

72 The currency in the CSO database is converted from Sweden Krona to USD based on average exchange rate in each year (0.153518 in 2013; 0.146947 in 2014 and 0.118707 in 2015).

73 A total of $\$ 0.011$ million of this was repayment (PMU, LO-TCO secretariat, and SSNC). The repayments are at transaction level and the aggregate value could be positive.

74 This included $\$ 0.04$ million in repayments.

75 See http://www.tzdpg.or.tz/dpg-website/sector-groups/otherroups/httpwwwtzdpgortzbudgetsupport.html.

76 https://www.open-contracting.org.

77 https://www.open-contracting.org/news/pledge-make-public-contracting-open-default-major-stepfighting-corruption/.

78 World Bank World Development Indicators poverty headcount ratio for 2011.

79 http://hdr.undp.org/sites/default/files/thdr2014-main.pdf.

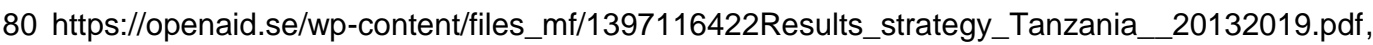

81 See

http://www.mof.go.tz/mofdocs/budget/Citizens\%20Budget/CITIZENS\%20BUDGET_\%20Final_English_ 
2013_14.pdf. According to the Tanzanian government, an increase in road and railway investment, which has a multiplier effect on agricultural development, was the reason for the agricultural budget cut.

82 Information provided by Morten Emil Hansen, Aid Policy Advisor, Oxfam Ibis.

83 See http://www.government.se/49b749/contentassets/32f9580fa76146998ef5bba49055cd4a/resultsstrategy-for-swedens-international-development-cooperation-in-tanzania-2013---2019.

84 Email to Oxfam from Carl Elmstam, Transparency Manager, SIDA, July 3, 2017.

85 See https://openaid.se/wp-content/files_mf/1482402746StrategirapportTAN2015.pdf; we used Google Translate to get a sense of what the document says, but the translation may not be exact.

86 Complementary roles for the OECD-DAC Creditor Reporting System and the International Aid Transparency Initiative, https://www.aidtransparency.net/news/new-papers-on-iati-and-the-crs-andaaa.

87 http://www.oecd.org/dac/genderdevelopment/aidinsupportofgenderequalityandwomensempowerment.htm.

88 SIDA's gender Policy marker https://www.sida.se/contentassets/fa74787eb621485096d7bc60e35c9518/18529.pdf.

89 http://www.tzdpg.or.tz/fileadmin/documents/dpg_internal/dpg_working_groups_clusters/prbs/Budget_S upport_in_Tanzania_2014-2015.pdf.

90 These NGOs are the Association of Local Authorities Tanzania, CCBRT (Comprehensive Community Based Rehabilitation Tanzania), FEMINA HIP, and the Tanzania Gender Networking Programme.

91 Government Offices of Sweden: Sweden's feminist foreign policy-examples from three years of implementation. http://www.government.se/information-material/2017/10/swedens-feminist-foreignpolicy--examples-from-three-years-of-implementation/

92 The thematic areas included in the proposed Constitution include (1) women's access to land and property rights in the context of inheritance; (2) supremacy of the Constitution, equality, and nondiscrimination; (3) women's representation in decision-making bodies; (4) integration of equity and equality principles throughout the Constitution; (5) marriage, family, and social welfare; (6) institutional framework for promotion, protection, and monitoring of gender-based rights; (7) consumer rights; and (8) Constitution-making process enhancement. Further to that, the analysis highlighted areas for improvement and recommendations, and the analysis was used as an advocacy tool that was shared with members of the Constituent Assembly during sessions in Dodoma.

93 Teaching and research institutes include universities, colleges, or other teaching institutions, research institutes, or think tanks.

94 Email from Melinda Cuzner, SIDA.

95 Email from Melinda Cuzner, SIDA.

96 The Tanzania Women Lawyers Association intends to implement a project on "Enhancing Good Governance, Accountability and Gender Equity." Specific objectives are to (1) advocate for good governance and accountability; (2) undertake gender-sensitive policy research and advocacy on legal reform; (3) promote respect for rights of vulnerable people, i.e., women and children; and (4) advocate for sexual and reproductive health and rights.

97 Email from Melinda Cuzner, SIDA.

98 Total ODA is used, instead of net ODA, since scholarship/training in a donor country does align with the country's education budget.

99 Budget Support in Tanzania (2014/2015)

http://www.tzdpg.or.tz/fileadmin/documents/dpg_internal/dpg_working_groups_clusters/prbs/Budget_S upport_in_Tanzania_2014-2015.pdf. See also Enzo C., Antonie K. and Andrew L. Assessing the impact of budget support: Case study in Mali, Tunisia and Zambia (2011) https://www.oecd.org/derec/50313762.pdf.

100 Budget Support in Tanzania (2014/2015).

101 See http://www.publishwhatyoufund.org/time-act-aid-budgets/.

102 Email from Melinda Cuzner, SIDA.

103 In an email, Melinda Cuzner of SIDA indicated to us that there are differing requirements, so reports are unlikely to be identical. Nevertheless, the agency is currently looking at how to achieve greater consistency across reports and greater transparency about why there are differences.

$104 \mathrm{Ms}$. Cuzner noted to us that accomplishing this might require changes in agency standard operating procedures. 
105 In an email, Melinda Cuzner of SIDA informed us that IATI had initially intended to achieve this but currently views it as too difficult.

106 See http://devinit.org/post/joined-up-data-alliance-announcement/.

107 For example, WB coded disbursement transaction as "D" while SIDA uses 3 to code disbursement transaction.

108 If the field under "Percentage of Swedish ODA allocated to each sector" is blank, it means that no ODA was allocated to that particular sector in that particular year.

109 Basic social services are defined to include basic education, basic health, basic nutrition, population/reproductive health, basic drinking water supply, and basic sanitation (IATI code list). 


\section{Research Reports}

This research report was written to share research results, to contribute to public debate and to invite feedback on development and humanitarian policy and practice. It does not necessarily reflect the policy positions of the publishing organizations. The views expressed are those of the author and not necessarily those of the publishers.

For more information, or to comment on this report, email marc.cohen@oxfam.org

(C) Oxfam International July 2018

This publication is copyright but the text may be used free of charge for the purposes of advocacy, campaigning, education, and research, provided that the source is acknowledged in full. The copyright holder requests that all such use be registered with them for impact assessment purposes. For copying in any other circumstances, or for re-use in other publications, or for translation or adaptation, permission must be secured and a fee may be charged. Email policyandpractice@oxfam.org.uk.

The information in this publication is correct at the time of going to press.

Published by Oxfam GB for Oxfam International under ISBN 978-1-78748-302-6 in July 2018. DOI: $10.21201 / 2018.3026$

Oxfam GB, Oxfam House, John Smith Drive, Cowley, Oxford, OX4 2JY, UK.

\section{DEVELOPMENT INITIATIVES}

Development Initiatives (DI) is an independent international development organisation working on the use of data to drive poverty eradication and sustainable development. Our vision is a world without poverty that invests in human security and where everyone shares the benefits of opportunity and growth. We work to ensure that decisions about the allocation of finance and resources result in an end to poverty, increase the resilience of the world's most vulnerable people, and ensure no one is left behind. To find out more about our work visit www.devinit.org or contact us at info@devinit.org.

\section{OXFAM}

Oxfam is an international confederation of 20 organizations networked together in more than 90 countries, as part of a global movement for change, to build a future free from the injustice of poverty. Please write to any of the agencies for further information, or visit www.oxfam.org. 